\title{
DZIALALNOŚĆ SANKTUARIUM MARYJNEGO W LEWICZYNIE W XX I XXI WIEKU NA TLE DZIEJÓW MIEJSCOWOŚCI I PARAFII ${ }^{1}$
}

\section{Zarys dziejów miejscowości, parafii i sanktuarium}

Początki sanktuarium w Lewiczynie na Mazowszu, sięgające połowy XVII wieku, doczekały się już w literaturze przedmiotu omówień szczegółowych². Brak jednak było opracowania o jego funkcjonowaniu w początkach XXI wieku. Niniejszy artykuł pragnie tę lukę w wypełnić, osadzając najnowsze dzieje lewiczyńskiego centrum życia religijnego, na tle wcześniejszej jego historii. Wykorzystano w nim przede wszystkim zasoby archiwum parafialnego w Lewiczynie, w którym znajdują się dokumenty z omawianego okresu. Są to: Kroniki parafialne (1945-2012), Księgi wizytacji kanonicznych, Księa cudów i łask, Księga pamiąkowa oraz Księga podziękowań i próśb do Matki Bożej Pocieszycielki Strapionych w Lewiczynie 15.08.1983-18.09.1993. Niezwykle istotne są też akta dotyczące prac budowlanych, konserwatorskich oraz relacji z władzami lokalnymi i państwowymi. Dokumentacja ta została zinwentaryzowana przez ks. Jana Makowskiego w $1966 \mathrm{r}$.

Należy zaznaczyć, że niektóre dokumenty, mogące wzbogacić wiedzę o losach sanktuarium i jego kustoszy (np. akta personalne duchowieństwa), nie są udostępniane z uwagi na zbyt krótki okres, jaki upłynął od momentu ich wytworzenia. Również archiwalia znajdujące się w Archiwum Państwowym Miasta Stołecznego Warszawy, a dotyczące poruszanej w pracy tematyki, były niedostępne z powodu reorganizacji sieci archiwów państwowych i wiążących się z tym przemieszczeń archiwaliów. W artykule wykorzystano również źródła drukowane i bogatą literaturę pomocnicząa .

* Krzysztof Perzyna - mgr historii, doktorant w Instytucie Historii KUL, e-mail: krzysztof. perzyna1987@gmail.com

${ }^{1}$ Autor składa podziękowanie za udostępnienie archiwum parafialnego księdzu kustoszowi Zdzisławowi Karasiowi, a także jego następcy - ks. Andrzejowi Juńczykowi.

${ }^{2}$ Zob. K. Perzyna, Sanktuarium maryjne w Lewiczynie 1962-2012, Lublin 2013, mps praca magisterska, Archiwum KUL.

${ }^{3}$ W. Bryndza, Krótka wiadomość o cudownym obrazie N.M.P. w Lewiczynie, Warszawa 1906; tenże, Księga cudów i lask Najświętszej Bogarodzicy Maryi w kościele lewiczyńskim zostającej, 
Wieś Lewiczyn znajduje się na starym szlaku łączącym Kraków z Warszawą, osiem kilometrów na południe od Grójca. Już w XI-XII wieku funkcjonował w pobliżu gród, z którego zachowały się do dnia dzisiejszego pozostałości stożkowatego nasypu o średnicy 30 metrów, a także wałów i fosy. Podczas prac wykopaliskowych odnaleziono monety z okresu wpływów rzymskich, kamienne narzędzia, kości zwierzęce oraz fragmenty naczyń glinianych ${ }^{4}$.

Zgodnie $\mathrm{z}$ dawną tradycją na terenie osady w średniowieczu miało dojść do bitwy, w której wojska księcia mazowieckiego odniosły zwycięstwo nad bliżej nieokreślonym wrogiem. Dla upamiętnienia tego wydarzenia usypane zostało wzgórze, na którym następnie wzniesiono kościół5. Pierwsza poświadczona źródłowo informacja o Lewiczynie pochodzi z wydanego w 1310 r. dokumentu, w którym wymieniony został pleban lewiczyński Maciej. Parafia lewiczyńska wchodziła w skład dekanatu grójeckiego, w archidiakonacie warszawskim, stanowiącym wschodnią część diecezji poznańskiej ${ }^{6}$. W 1798 roku, stała się ona częścią nowo utworzonej diecezji warszawskiej w ramach dekanatu grójeckiego.

Lewiczyn przez wieki był jedną z typowych osad tej części Mazowsza. Przeważała w nich drobna szlachta, która gospodarowała na coraz bardziej rozdrobnionych działach ziemi ${ }^{7}$. Pod koniec XVIII w. pojawiają się wzmianki o Żydach, a w połowie XIX w., po powstaniu styczniowym, o Rosjanach osadzonych w skonfiskowanych dobrach kościelnych (jeszcze przed 1905 r. większość z nich wyjechała do Rosji). Sytuacja materialna wielu mieszkańców Lewiczyna na początku XX w., a także w okresie międzywojennym była trudna, jak zresztą większości mieszkańców dawnego zaboru rosyjskiego. Zapóźnienie ekonomiczne oraz ciężkie warunki gospodarowania sprawiły, że były to tereny ubogie.

Podczas II wojny światowej Lewiczyn wchodził w skład Generalnego Gubernatorstwa. Miejscowość była świadkiem działania grupy AK „Głuszec” Grójec. Ówczesny proboszcz ks. Kazimierz Łuczak był kapelanem oddziału partyzanckiego, a na wieży kościoła ukrywano radiostację . $^{8}$

Sytuacja ekonomiczna Lewiczyna uległa zmianie w latach 60. XX wieku, kiedy w powiecie grójeckim zaczęto zakładać sady owocowe, które stały się głównym źródłem zamożności mieszkańców regionu. Na terenie Lewiczyna i okolicznych miejscowości w $1962 \mathrm{r}$. sady stanowiły ok. 12\% powierzchni użytków rolnych, by do końca lat 80 . wyprzeć inne gałęzie rolnictwa9 .

Warszawa 1911; A. Fridrich, Historie cudownych obrazów NMP w Polsce, t. 3, Kraków 1908; W. Malej, Sanktuaria maryjne Archidiecezji Warszawskiej, Rzym 1966; Z. Szeląg, Grójecczanie sami o sobie. Antologia korespondencji prasowej lat 1889-1959. Cz.2 1906-1946, Grójec 2008; $Z$ dawna Polski Tyś Królową. Przewodnik po sanktuariach maryjnych, wyd. 5, popr. i uzup., Szymanów 1999; W, Zaleski, Sanktuaria polskie, Warszawa 1988.

${ }^{4}$ A. Spyk, R. Spyk, Zamki i warownie ziemi mazowieckiej, Warszawa 2002, s. 47.

${ }^{5}$ G. Kalwarczyk, Dekanat grójecki w archidiecezji warszawskiej, Warszawa 2001, s. 66.

${ }^{6}$ J. Nowacki, Archidiecezja poznańska w granicach historycznych i jej ustrój, Poznań 1964, S. 530

${ }^{7}$ R. Matyjas, Kult Matki Bożej Lewiczyńskiej XVII-XVIII w. Cuda i wyznawcy, Warszawa 1992, s. 5.

${ }^{8}$ Tenże, Smak XX wieku, Grójec 1998, s. 229-233.

${ }^{9}$ Tenże, Powiat grójecki w latach 1945-1975, Grójec 2006, s. 124-134. 
Parafia pw. śś. Wojciecha i Marcina, wyodrębniona z parafii w Grójcu, powstała prawdopodobnie już w XIII wieku. Za takim datowaniem może przemawiać rozległość terytorialna dawnej parafii lewiczyńskiej, na którą składało się 18 wiosek. W XVIII w. z jej terytorium wydzielono jednostkę kościelną w Belsku Dużym $^{10}$. Głównymi opiekunami (kolatorami) kościoła lewiczyńskiego do końca XVI wieku byli Lewiccy z Lewiczyna herbu Prawda. Zachowały się wzmianki o prężnie działającej w tamtych czasach szkole parafialnej. Jednym z jej uczniów był prawdopodobnie Jakub z Zaborowa, kanonik krakowski, doktor dekretałów i rektor Akademii Krakowskiej ${ }^{11}$.

Według świadectwa biskupa poznańskiego Wawrzyńca Goślickiego, wizytującego Lewiczyn w 1603 r., ówczesny kościół parafialny, w którym znajdowały się trzy ołtarze w dobrym stanie był obszerny, jednak groził zawaleniem ze starości. Obecna świątynia wzniesiona została w latach 1606-1608 z fundacji podstolego czerskiego Prokopa Oborskiego herbu Pierzchała vel Roch, a konsekrowano ją 27 kwietnia 1608 r. ${ }^{12}$ Jest to budowla orientowana, o konstrukcji zrębowej, wzmocnionej kleszczami (tzw. lisice), oszalowana z zewnątrz deskami, z nawą zbliżoną do kwadratu $(10,60 \times 11,20 \mathrm{~m})$ i węższym prezbiterium $(12,30 \times 8,60 \mathrm{~m})$ zamkniętym trójbokiem. Dobudowaną do niego zakrystię poprzedza nowsza kruchta. Do nawy od południa przylega późniejsza kruchta boczna, a od zachodu - kruchta główna, mająca szerokość nawy i zwieńczona masywną czworoboczną wieżą. Nawa i prezbiterium przykryte są oddzielnymi, blaszanymi dachami dwuspadowymi, zakrystia daszkiem pulpitowym, kruchta boczna dachem trójpołaciowym, wieża zaś obeliskowym ${ }^{13}$.

Tworzenie ośrodka kultowego w Lewiczynie zapoczątkowało w październiku 1665 r. objęcie probostwa przez ks. Andrzeja Gołkowskiego herbu Strzemię, który przyczynił się do odnowy życia religijnego ${ }^{14}$. Dla ożywienia kultu maryjnego, nauczał wiernych modlitwy różańcowej, której, jak wspominał, prawie wówczas w tych stronach nie znano. W dość krótkim czasie przy kościele parafialnym powołał kilka bractw: Szkaplerza Świętego, różańcowe, Najsłodszego Imienia Jezus i Błogosławionej Maryi Dziewicy, św. Izydora Oracza, Najświętszego Sakramentu i Niepokalanego Poczęcia NMP. Przynależność do bractw dawała liczne przywileje w postaci odpustów, lecz jednocześnie nakładała też określone obowiązki religijne m.in. odmawiania określonych modlitw, spotykania się na zebraniach (tzw. „schadzki”), czy też „obrony świętej wiary katolickiej”. W tworzeniu bractw proboszcz lewiczyński mógł liczyć na pomoc duchowieństwa zainteresowanego krzewieniem kultu maryjnego, dominikanów z Warki i karmelitów z Lipia, którzy propagowali odpowiednio nabożeństwo różańcowe i bractwo szkaplerzne ${ }^{15}$.

${ }^{10}$ Nowacki, Archidiecezja poznańska w granicach historycznych, s. 533.

${ }^{11}$ Tamże, s. 533.

${ }^{12}$ Matyjas, Kult Matki Bożej Lewiczyńskiej, s. 12; T. Gołąb, Madonna, co z cedrowej deski pociesza, „Gość Niedzielny”, 29 (2001) s. 14.

${ }^{13}$ J.A. Wiśniowski, Kościoły drewniane Mazowsza, Pruszków 1998 s. 74-76.

${ }^{14}$ Matyjas, Kult Matki Bożej Lewiczyńskiej, s. 68-69.

${ }^{15}$ Tamże, s. 16-18. W. Malej, Sanktuaria maryjne Archidiecezji Warszawskiej, Rzym 1966, s. 4. 
Ośrodkiem życia duchowego, który szczególnie odcisnął swoje piętno na Lewiczynie, była Góra Kalwaria ${ }^{16}$, mająca być w założeniu jej fundatora, biskupa poznańskiego Stefana Wierzbowskiego, idealnym miastem chrześcijańskim, Nowym Jeruzalem i ośrodkiem kultu Męki Pańskiej. Proboszcz lewiczyński ks. Gołkowski był członkiem sprawującej opiekę nad Kalwarią kongregacji filipinów, a jego parafia stała się w pewnym sensie dopełnieniem idei bpa Wierzbowskiego, który wspierał zapoczątkowane przez Gołkowskiego dzieło. Wielką pomocą dla proboszcza byli Grzybowscy herbu Prus II, jedna z najmożniejszych rodzin w ziemi czerskiej, z której wywodzili się patronowie kościoła lewiczyńskiego ${ }^{17}$. Dzięki wsparciu Teofila Grzybowskiego w latach 1667-1673 odnowiono i przyozdobiono kościół, aby uczynić go godną oprawą dla otaczanego kultem wizerunku Matki Bożej, który znalazł się w nowym ołtarzu głównym. W 1678 r. staraniem ks. Gołkowskiego obraz Matki Bożej otrzymał sukienkę ze srebrnej blachy, wykonaną przez warszawskiego złotnika Grzegorza Wróblewicza ${ }^{18}$. Odnowiono wówczas wnętrze świątyni, ołtarze boczne zyskały nowe mensy, powstał również nowy ołtarz, w którym umieszczono obraz św. Izydora, patrona rolników. W kościele położono nową podłogę dębową. Wtedy to zaczęto nazywać świątynię lewiczyńską „Świętą Bazyliką”, co miało podkreślać jej znaczenie religijne dla ziemi czerskiej i południowego Mazowsza, jako miejsca kultu sławnego już wówczas obrazu NMP ${ }^{19}$.

Historia wizerunku nie jest dokładnie znana. Z wydanego 2 lipca $1684 \mathrm{r}$. orzeczenia bpa Wierzbowskiego, stwierdzającego cudowność wspomnianego wizerunku, wynika, że znajduje się on w Lewiczynie od 1604 r. Najprawdopodobniej obraz sprowadzili tutaj synowie Prokopa Oborskiego, pobierający nauki w Rzymie ${ }^{20}$. Jest to jeden z wielu wizerunków namalowanych na wzór ikony $S a-$ lus Populi Romani, zwanej też Matką Bożą Śnieżną, znajdującej się w rzymskiej bazylice Santa Maria Maggiore. Obraz ten w dobie kontrreformacji zaczął cieszyć się szczególnym kultem, promieniującym daleko poza granice Wiecznego Miasta. Przedstawia Matkę Bożą z dzieciątkiem Jezus na rękach; Maria ubrana jest $\mathrm{w}$ czerwoną suknię i niebieską chustę, która spływa na jej ramiona, a Jezus w czerwone szaty z bufiastymi rękawami. Charakterystyczny jest układ rąk Maryi prawa dłoń spoczywa na lewej, podtrzymującej Jezusa. Było to przedstawienie bardzo rozpowszechnione na ziemiach polskich w końcu XVI i na początku XVII w ${ }^{21}$. Według ocen historyków sztuki, obraz z sanktuarium lewiczyńskiego powstał w ostatniej ćwierci XVI w.

${ }^{16}$ Góra Kalwaria - miasto założone przez biskupa poznańskiego Stefana Wierzbowskiego. Prawa miejskie posiada od 1670 roku. Miała być miejscem szczególnego kultu Męki Pańskiej.

${ }^{17}$ Matyjas, Kult Matki Bożej Lewiczyńskiej, s. 16-25.

${ }^{18}$ Tamże, s. 12.

${ }^{19}$ Tamże, s. 12-13.

${ }^{20}$ Synowie Prokopa Oborskiego, Mikołaj (1576-1646) jezuita oraz Tomasz (1571-1645) w latach 1614-1645 sufragan krakowski.

${ }^{21}$ Archiwum Parafii Lewiczyn (dalej: APL), Opis historyczny o kulcie, starożytności i wartości historycznej cudownego obrazu Matki Bożej Lewiczyńskiej, s. 2; G. Kalwarczyk, Dekanat grójecki $w$ archidiecezji warszawskiej, Warszawa 2001, s. 70. 
Dokonane w kontekście tego obrazu cuda opisuje Księga cudów i łask, których doznawali i po dziś dzień doznaja tak wiele ludzi, którzy się w różnych utrapieniach, dolegliwościach, $w$ chorobach ciężkich i różnych nieszczęściach $z$ wielka ufnościa i zupetna wiarq uciekali do Najświętszej Boga Rodzicy Maryjej Panny, tu w kościele lewczyńskim pozostającej. Rękopis, oprawiony w 1706 r., zawiera opis przeszło siedmiuset cudów stwierdzonych do XIX w.

Napływ pielgrzymów oraz doniesienia o cudach i łaskach uzyskanych za wstawiennictwem Matki Bożej Lewiczyńskiej skłoniły władze kościelne do zbadania prawdziwości tych wydarzeń. Komisje biskupie z lat 1678-1679 przebadały sprawy cudów mających miejsce w Lewiczynie, przesłuchały świadków oraz zapoznały się ze zgromadzonymi świadectwami. W dniu 2 lipca 1684 r., na czele trzeciej już komisji, przybył do Lewiczyna sam bp Wierzbowski, który po kolejnym zapoznaniu się ze zgromadzonymi materiałami wydał dokument stwierdzający cudowność lewiczyńskiego wizerunku i polecił, aby ogłosić to do wiadomości wiernych ${ }^{22}$. Było to ukoronowanie starań ks. Gołkowskiego oraz Samuela Grzybowskiego, który również aktywnie włączył się w prace zmierzające do uczynienia z Lewiczyna znaczącego ośrodka pielgrzymkowego. Przy wizerunku Pani Lewiczyńskiej powieszono liczne wota, ozdobiono nimi ściany prezbiterium i ołtarze boczne, których w owym czasie było siedem. W 1742 r. w kościele postawiono ósmy ołtarz boczny, z wyobrażeniem Chrystusa Ukrzyżowanego ${ }^{23}$.

W kontekście tworzeniu ośrodka kultu maryjnego w Lewiczynie wypada powiedzieć więcej o jednym z bractw powołanych przez ks. Gołkowskiego, noszącym nazwę Niepokalanego Poczęcia NMP, które powstało w 1694 r. i odcisnęło piętno na duchowym obliczu sanktuarium. Promotor bractwa był zobowiązany do odprawiania dwóch mszy w tygodniu przed cudownym obrazem, śpiewania wraz z ludem Oficjum o Niepokalanym Poczęciu NMP oraz opieki nad wotami. Miał również na stałe rezydować przy sanktuarium. Istniało też zastrzeżenie, że nie może on jednocześnie być proboszczem parafii lewiczyńskiej. Tak, więc od roku 1742 można mówić o ustanowieniu funkcji kustosza sanktuarium i opiekuna cudownego obrazu ${ }^{24}$.

Dogmat o Niepokalanym Poczęciu NMP został przez Kościół katolicki ogłoszony dopiero w 1854 r., ale kult NMP w tajemnicy Niepokalanego Poczęcia w Lewiczynie należy łączyć z osobą ks. Stanisława Papczyńskiego, założyciela Zgromadzenia Księży Marianów, który został uzdrowiony przed cudownym wizerunkiem ${ }^{25}$. Ks. Papczyński często głosił kazania w lewiczyńskim kościele i prowadził ożywioną działalność duszpasterską. Pamięć o nim zachowała się na długo, a bez jego wpływu trudno wyobrazić sobie późniejsze utworzenie bractwa Niepokalanego Poczęcia. Można go nawet określić duchowym ojcem sanktuarium lewiczyńskiego. Na początku XVIII w. Grzybowscy starali się, aby nowo

${ }^{22}$ Matyjas, Kult Matki Bożej Lewiczyńskiej, s. 26-29.

${ }^{23}$ Tamże, s. 12-15; APL, Opis historyczny o kulcie, starożytności i wartości historycznej cudownego obrazu Matki Bożej Lewiczyńskiej, s. 2-5; A. Fridrich, Historie cudownych obrazów NMP w Polsce, t. 3, Kraków 1908, s. 131-133.

${ }^{24}$ Matyjas, Kult Matki Bożej Lewiczyńskiej, s. 21; APL, Opis historyczny o kulcie, s. 9.

${ }^{25}$ Marianie, red. J. Bukowicz, Stockbridge 1968, s. 8-16. 
powstały zakon marianów otoczył opieką duszpasterską pielgrzymów przybywających do Lewiczyna, jednak bezskutecznie.

Czcicielami Matki Bożej Lewiczyńskiej byli ludzie, którzy na stałe wpisali się w dzieje kraju. Jednym z nich był starosta grójecki Zygmunt Zbierzchowski, bohater bitwy wiedeńskiej. Najprawdopodobniej to on przywiózł do Lewiczyna wotum króla Jana III - ozdobny materiał pochodzący z namiotu tureckiego wezyra ${ }^{26}$.

Około 1680 r. Lewiczyn stanowił ważny punkt na mapie religijnej Polski, niemogący wprawdzie równać się z Jasną Górą czy Studzianną, lecz mimo to należący do czołowych, a na Mazowszu być może najważniejszy ośrodek pielgrzymkowy. Do obsługi przybywających pielgrzymów potrzeba było od pięciu do siedmiu duchownych, którzy na stałe rezydowali przy kościele lewiczyńskim, co może świadczyć o randze tego miejsca. Na podstawie Księgi cudów oraz ksiąg brackich można w przybliżeniu ustalić także zasięg kultu: na północy okolice Łomży, na południu - Krakowa, na zachodzie - Poznania, na wschodzie zaś Lwowa. Najwięcej wyznawców pochodziło jednak z historycznego Mazowsza, z ziemi czerskiej i warszawskiej ${ }^{27}$.

$\mathrm{Na}$ początku XVIII wieku, w wyniku zniszczeń wojny północnej, kult ten nieco podupadł, ograniczając się do województwa mazowieckiego oraz sąsiednich województw Korony. Na kryzysie zaważył również brak godnych następców ks. Gołkowskiego, który zakończył swoją posługę duszpasterską w 1693 r. Jego następcy byli bardziej zainteresowani zrobieniem kariery dzięki znanemu miejscu pielgrzymkowemu, niż prowadzeniem pracy duszpasterskiej. Pojawiły się problemy materialne sanktuarium, zmalała rola bractw religijnych, które nie mogły należycie funkcjonować z powodu braku środków finansowych oraz zaniedbań duszpasterskich. Chwalebnym wyjątkiem może tu być postać ks. Wilskiego (1730-1769), który włożył sporo wysiłku w remont kościoła i starał się o odnowienie bractw. Podczas powstania kościuszkowskiego w Lewiczynie przebywał naczelnik Tadeusz Kościuszko, który w tutejszej plebani miał układać plany obrony Warszawy ${ }^{28}$.

Okres rozbiorów w końcu XVIII w., oznaczał również kres świetności sanktuarium w Lewiczynie. W wyniku podziału kraju między państwa zaborcze zasięg kultu Matki Bożej Lewiczyńskiej uległ ograniczeniu do terenu Mazowsza ${ }^{29}$. Poważnym ciosem dla Lewiczyna były represje po upadku powstania styczniowego, kiedy rząd carski skonfiskował dobra kościelne, zlikwidował bractwa religijne, a proboszcza ks. Józefa Johna, skazał na dwadzieścia pięć lat zesłania na Syberii. Represje były wynikiem zaangażowania się duchownych lewiczyńskich w pomoc powstańcom. Dodatkowo władze carskie zdecydowały się na przesunięcie na wschód trasy łączącej Kraków ze stołeczną Warszawą, nazywaną ,gościńcem”, która do tej pory przebiegała u podnóża pagórka, na którym wznosił się kościół. Decyzja ta spowodowała powolny upadek sanktuarium. Od tej pory przybywa-

${ }^{26}$ R. Matyjas, Powiat grójecki na scenie wieków, Grójec 2010, s. 12-13.

${ }^{27}$ Tenże, Kult Matki Bożej Lewiczyńskiej, s. 14; tenże, Lewiczyn. Z dziejów kultu maryjnego, „Mówią Wieki”, 7 (1991) s. 24-28.

${ }_{28}$ Tamże, s. 15-25.

${ }^{29}$ T. Lubomirski, Księgi Ziemi Czerskiej, Warszawa 1879, s. XXXII. 
ły do niego głównie pielgrzymki z najbliższej okolicy. Mimo trudnej sytuacji, w ostatnim dwudziestoleciu XIX wieku z pomocą nowych właścicieli Lewiczyna, rodziny Zielińskich, udało się ks. Tomaszowi Chtrempińskiemu wyremontować kościół oraz uporząadkować jego otoczenie. W 1883 roku sukienkę Matki Bożej umieszczono na błękitnym płótnie, a nad głowami Bogurodzicy i Jej Syna pojawiło się dwanaście gwiazd.

W wyniku wydarzeń 1905 r. w Cesarstwie Rosyjskim i wydaniu przez cara Mikołaja II dekretu tolerancyjnego Kościół katolicki mógł rozpocząć bardziej aktywne działanie na polu duszpasterskim. Od 1903 r. proboszczem w Lewiczynie został ks. Wojciech Bryndza. Impulsem do ożywienia ruchu pielgrzymkowego do sanktuarium było uwolnienie wsi Otaląż od tyfusu plamistego za wstawiennictwem Matki Bożej. Pojawił się też zamysł koronacji cudownego obrazu. Ks. Bryndza rozpoczął zbieranie dokumentacji, spisywał uzdrowienia i łaski, napisał także prośbę o zgodę w tej sprawie do arcybiskupa Popiela, pod którą podpisali się najznamienitsi obywatele ziemi grójeckiej, m.in. książęta Lubomirscy, dziedzice pobliskiego majątku w Małej Wsi. Ks. Bryndza na podstawie dostępnych mu archiwaliów opracował m.in. dwie broszury, dotyczące kultu Matki Bożej Lewiczyńskiej ${ }^{30}$. Zorganizował kwestę na remont kościoła i rozpoczął gromadzenie materiałów na budowę murowanej dzwonnicy, która miała się stać muzeum gromadzącym pamiątki związane $\mathrm{z}$ sanktuarium i kultem cudownego obrazu. W 1912 r. kuria nakazała jednak przerwanie budowy wieży, zaniechano również starania o koronację.

W okresie międzywojennym Lewiczyn ożywał tylko w okresie największych świąt - uroczystych odpustów, kiedy do sanktuarium przybywały pielgrzymki. W świadomości miejscowych była to jednak nadal „Mazowiecka Częstochowa”, chociaż próżno by doszukiwać się w tym czasie rozmachu uroczystości z siedemnastego wieku.

Lata II wojny światowej były dla sanktuarium okresem niezwykle ciężkim. Pod nieobecność ks. Kazimierza Łuczaka, który na krótko opuścił parafię w obawie przed zbliżającym się wojskiem niemieckim, zaginęło wiele archiwaliów. Po powrocie zastał na plebanii rezydujących tam Niemców i uciekinierów. Zginęło dużo wotów, cenniejszych naczyń liturgicznych i książek. Rozbity został zabytkowy kamienny stół, przy którym według tradycji miał układać plany obrony Warszawy Tadeusz Kościuszko ${ }^{31}$. W 1944 r. pod gruzami Muzeum Archidiecezji Warszawskiej bezpowrotnemu zniszczeniu uległa część dokumentacji dotyczącej sanktuarium i parafii lewiczyńskiej, znajdujących się pierwotnie w archiwum parafialnym oraz pas słucki. Rzeczy te zostały na polecenie kurii metropolitalnej przekazane w 1934 r. do Warszawy przez ówczesnego proboszcza ks. Włodzimierza Błońskiego ${ }^{32}$.

${ }^{30}$ Bryndza, Krótka wiadomość o cudownym obrazie NMP; tenże, Księga cudów i łask Najświętszej Bogarodzicy Maryi w kościele lewiczyńskim; Z. Szeląg, Grójecczanie sami o sobie. Antologia korespondencji prasowej lat 1889-1959. Cz. 2: 1906-1946, Grójec 2008, s. 30-31.

${ }^{31}$ APL 41/1, Kronika parafialna 1945-1980, s. 1-2.

${ }^{32}$ R. Matyjas, Z dziejów Grójecczyzny, Grójec 1999, s. 81. 
Po zakończeniu działań wojennych nowy proboszcz, ks. Romuald Kozłowski, który objął parafię lewiczyńską w 27 września 1945 r., stwierdził bardzo zły stan dachu kościoła, jak również kruchty od strony północnej. Zabrał się, więc do prac remontowych, aby przywrócić świątyni godny wygląd $\mathrm{d}^{33}$. Udało mu się przeprowadzić pomyślnie elektryfikację kościoła i budynków parafialnych. Nie powiodły się jednak próby ożywienia lewiczyńskiego sanktuarium. Zadania przywrócenia świetności sanktuarium podjął się nowy kustosz i proboszcz w Lewiczynie, ks. Jan Makowski.

\section{Lewiczyn na tle innych sanktuariów archidiecezji warszawskiej}

Zgodnie z definicją sanktuarium to:

kościół, w którym znajduje się otoczony czcią obraz bądź figura Jezusa Chrystusa, Marii, świętych, znaczące relikwie lub miejsce święte słynące z cudownych zjawisk (objawienia, uzdrowienia), stanowiące cel pielgrzymek wiernych za aprobatą biskupa miejscowego ${ }^{34}$.

Kodeks Prawa Kanonicznego z 25 stycznia 1983 r., obok podania definicji, wprowadza trzy rodzaje sanktuariów: diecezjalne, krajowe oraz międzynarodowe. To rozróżnienie pociąga za sobą także podporządkowanie kościelne; sanktuaria diecezjalne znajdują się w jurysdykcji miejscowego ordynariusza, krajowe Konferencji Episkopatu, natomiast międzynarodowe - Stolicy Apostolskiej ${ }^{35}$.

W dekanacie grójeckim rangę sanktuarium maryjnego posiada tylko Lewiczyn. Jest on najprawdopodobniej najstarszym sanktuarium oficjalnie uznanym przez władze kościelne na terenie obecnej archidiecezji warszawskiej. Liczne rzesze pielgrzymów ściągają tu na odpusty, których w sanktuarium jest sześć w ciągu roku (najwięcej w dekanacie grójeckim). Duszpasterstwo w sanktuarium m.in. nawiedzenia obrazu w parafiach dekanatu grójeckiego oraz dekanatów sąsiednich sprawiło, że Lewiczyn jest postrzegany, jako „mała Częstochowa” całego regionu grójeckiego i historycznego południowego Mazowsza. Obok Warszawy i Niepokalanowa, Lewiczyn zajmuje czołowe miejsce na mapie ośrodków kultowych archidiecezji.

\section{Rola duchowieństwa w ożywienie kultu Matki Bożej Lewiczyńskiej - Pani Ziemi Grójeckiej na przełomie XX i XXI wieku}

Do odnowienia kultu NMP w Lewiczynie znacząco przyczynił się ks. J. Makowski, od 21 czerwca 1962 r. sprawujący funkcję kustosza sanktuarium ${ }^{36}$. Pierw-

${ }^{33}$ APL 41/1, Kronika parafialna 1945-1980, s. 1-3.

${ }^{34}$ W. Pałęcki, Sanktuarium, w: Encyklopedia katolicka, t. 17, Lublin 2012, kol. 1058-1059.

35 J. Dudziak, Prawno-kanoniczne koncepcje sanktuarium, „Tarnowskie Studia Teologiczne”, 9 (1983) s. 60-73.

${ }^{36}$ Ks. Makowski Jan (1925-2013) - kapłan diecezji warszawsko-praskiej. Urodził się w Pruszkowie, jako syn Adama i Bronisławy z domu Laskowska. Magisterium z teologii uzyskał na Uniwersytecie Warszawskim. Święcenia kapłańskie otrzymał 16 grudnia 1951 r. z rąk kard. S. Wyszyńskiego. Był wikariuszem w parafiach: Goszczew, Karczew, Radzymin, Warszawa-Radość, Warszawa-Anin. W czerwcu 1962 r. został proboszczem w parafii Lewiczyn, dek. Grójec (arch. warszaw- 
szym jego zadaniem było przeprowadzenie remontu zabytkowej świątyni, szczególnie podwalin pod ścianą północną, ponieważ kościół wraz z jego najbliższym otoczeniem - dzwonnicą i cmentarzem przykościelnym został uznany za zabytek przez wojewódzkiego konserwatora zabytków, jako cenny przykład siedemnastowiecznej architektury drewnianej na Mazowszu ${ }^{37}$. O potrzebie restauracji zabytków mówił protokół powizytacyjny bpa Wacława Majewskiego, wspominający o szczególnej wartości zgromadzonych w lewiczyńskiej świątyni dzieł sztuki oraz paramentów liturgicznych, obligujący proboszcza do jak najszybszego przeprowadzenia prac restauracyjnych, przy uwzględnieniu możliwości materialnych parafii ${ }^{38}$.

Nowy kustosz podjął działania propagujące kult lewiczyńskiego wizerunku. 14 kwietnia 1963 r. uroczyście poświęcono umieszczoną na zewnętrznej ścianie kościoła kopii obrazu Matki Bożej. Obraz był autorstwa Sylwii Lewandowskiej z Kuss, która też w 1964 roku ozdobiła jeden z ornatów podobizną Matki Bożej Lewiczyńskiej ${ }^{39}$. Zakupiony został również jeszcze jeden ornat przedstawiający lewiczyński wizerunek, który używano podczas uroczystości maryjnych ${ }^{40}$.

W dniu 14 lipca 1966 r. artysta malarz Julian Hermel z Warszawy, polecony przez warszawską kurię, dokonał oględzin cudownego obrazu Matki Bożej Lewiczyńskiej ${ }^{41}$. Według jego oceny obraz wymagał m.in. uzupełnienia ubytków powstałych w warstwie malarskiej, oczyszczenia i zabezpieczenia odwrocia obrazu, nałożenia warstwy werniksu na lico ${ }^{42}$. Wizerunek oddano do konserwacji w lutym 1967 r. Prace przeprowadziła w Muzeum Narodowym w Warszawie Aldona Romanowicz - uznany konserwator zabytków ${ }^{43}$. Sporządzono wówczas niezbędną dokumentację oraz - na podstawie „szczegółów kostiumologicznych” - określono pochodzenie obrazu na początek XVII stulecia ${ }^{44}$. Wizerunek powrócił do Lewiczyna w czerwcu 1967 r. Wspomniany Julian Hermel wykonał wówczas jego kopię, a sukienkę wraz z koronami - Adam Makowski z Warszawy. Wykorzystywano ją podczas uroczystości odpustowych i nawiedzeń w parafiach dekanatu grójeckiego i poza jego granicami. Działania te były etapem w przygotowaniach do korona-

ska). Od czerwca 1977 r. proboszcz parafii Biała Rawska i dziekan bialski. W latach 1986-1991 proboszcz parafii, pw. św. Jana Chrzciciela w Pniewniku. W sierpniu 1991 r. przeszedł na emeryturę i zamieszkał w domu księży emerytów w Warszawie-Otwocku. Ks. Jan Makowski ps. „Orzeł”, Mój życiorys (Otwock 2 lutego 2009 roku), w: http://diecezja.waw.pl/3109 (dostęp 27.09.2016).

${ }^{37}$ APL 18, Dokumenty - Dokumenty dotyczące remontu kościoła parafialnego w Lewiczynie, k. 228; Z. Kiełbowska, Parafia Lewiczyn w latach 1945-1995, Warszawa 2001, s. 46-47, mps pracy magisterskiej, Archiwum PWT w Warszawie.

${ }^{38}$ APL 54/1, Księga wizytacji - Liber visitationum episcopalium et decanalium ecclesiae Levicinensis ab amo 1891-1982, s. 14.

${ }^{39}$ APL 41/1, Kronika parafialna 1945-1980, s. 35-37.

${ }^{40}$ Kiełbowska, Parafia Lewiczyn w latach 1945-1995, s. 124.

${ }^{41}$ APL 18, Dokumenty dotyczące remontu kościoła parafialnego w Lewiczynie, k. 215.

${ }^{42}$ Tamże.

${ }^{43}$ APL 41/1, Kronika parafialna 1945-1980, s. 39: Matyjas, Z dziejów Grójecczyzny, s. 82.

${ }^{44}$ APL, Romanowicz A., Opis prac konserwatorskich, wykonanych przy Obrazie Matki Boskiej z Dzieciątkiem z głównego ołtarza kościoła parafialnego w Lewiczynie - Notatka ikonograficzna rok 1967. 
cji papieskiej cudownego obrazu. Kopię uroczyście poświęcono podczas odpustu Wniebowzięcia NMP 15 sierpnia $1970 \mathrm{r}^{45}$

Ponieważ ks. Makowski był usatysfakcjonowany z efektów prac konserwatorskich, oddał do renowacji w tej samej pracowni inne obrazy znajdujące się w kościele. Konserwacji poddano sześć obrazków wotywnych, ukazujących cuda dokonane za wstawiennictwem Matki Bożej Lewiczyńskiej. W 1970 r. powróciły z pracowni konserwatorskiej kolejne dzieła sztuki: obrazy przedstawiające św. Józefa, św. Kajetana z Tieny, św. Annę, św. Antoniego oraz obraz Niepokalanego Poczęcia NMP, których renowacji dokonały Aldona Romanowicz i Maria Wodzińska ${ }^{46}$. Przy okazji tych prac głośno było o obrazie przedstawiającym św. Izydora, którego bardzo wnikliwą analizę malarską przeprowadziły Izabela Galicka i Hanna Sygietyńska. Wyniki swoich prac przedstawiły w artykule zamieszczonym w „Biuletynie Historii Sztuki”47.

Dzięki zapobiegliwości proboszcza, wiele dzieł sztuki odzyskało świetność. Odnaleziony pod schodami prowadzącymi na chór zabytkowy krzyż, po konserwacji w Muzeum Narodowym w Warszawie, umieszczono w kruchcie. Dwa obrazy, będące jak to określił: ,,w opłakanym stanie”, odnowił Julian Hermel. Ks. Makowski odnalazł również lichtarze pocięte i przerobione na lampiony, pochodzące z XVII w., a wykonane przez warszawskiego złotnika Grigla. Do pierwotnego stanu przywrócił je Wacław Majewski z Warszawy. Pomocne przy konserwacji okazały się zdjęcia archiwalne udostępnione przez Wydział Historii Sztuki PAN ${ }^{48}$.

W lipcu 1971 r. wymieniona została częściowo blacha cynowa na kościele i wieży. Ks. Makowski wysłał także prośbę do wojewódzkich władz konserwatorskich o zezwolenie na wymianę dachu na całym kościele i wieży ${ }^{49}$. W tym też roku odnowiono XVIII-wieczną monstrancję, do której dorobiono dwa brakujące aniołki oraz uzupełniono kamienie szlachetne ${ }^{50}$.

Wnętrze świątyni również uległo przeobrażeniu. Zgodnie z dekretami Soboru Watykańskiego II wykonano w kościele ołtarz „twarzą do ludu”, nawiązujący stylem do wnętrza świątyni oraz ołtarz Słowa Bożego i fotel do miejsca przewodniczenia, w stylu Ludwika XV. Ułożono również nowe podium i podłogę, również w kruchcie kościoła ${ }^{51}$. Przy świątyni ustawiono dwie gabloty, w których umieszczono informacje o historii sanktuarium i znajdujących się w nim zabytkach.

W styczniu 1972 r. powróciły do świątyni z renowacji ostatnie dzieła sztuki. W sierpniu ks. Makowski, jako kustosz sanktuarium został delegowany przez kurię do Niepokalanowa, na Kongres Mariologiczny ${ }^{52}$.

${ }^{45}$ APL 41/1, Kronika parafialna 1945-1980, s. 46-48.

${ }^{46}$ APL 41/1, Kronika parafialna 1945-1980, s. 46; Kiełbowska, Parafia Lewiczyn $w$ latach 1945-1995, s. 47-48.

${ }^{47}$ APL 41/1, Kronika parafialna 1945-1980, s. 41; I. Galicka, I. Sygietyńska, Erazm Wąsowski - nieznany malarz XVII w. i jego dzieło w Lewiczynie, „Biuletyn Historii Sztuki”, 1 (1970) s. 74; Matyjas, Z dziejów Grójecczyzny, s. 82.

${ }^{48}$ APL 41/1, Kronika parafialna 1945-1980, s. 50-51.

${ }^{49}$ Tamże, s. 52.

${ }^{50}$ Tamże, s. 53

${ }^{51}$ Tamże, s. 52-53.

${ }^{52}$ Kiełbowska, Parafia Lewiczyn, s. 124. 
Ks. Makowski, który stale zachęcał wiernych do składnia wotów, zabezpieczał je przez umieszczenie ich w specjalnych gablotach. Niektóre, o szczególnej wartości zostały schowane w bezpiecznym miejscu ${ }^{53}$. Liczba wotów zmieniała się. W 1945 r., było 59 sztuk różnego rodzaju wotów: srebrnych, złotych, pozłacanych i mosiężnych, a także kilku sznurów korali i sztucznych pereł. W lipcu 1952 r. zawieszono przy cudownym obrazie kolejne 95 sztuk wotów. Część z nich były to dary ofiarowane w latach 1945-1952. W latach 1973-1975 ofiarowano 83 sztuki wotów ze srebra i 10 sznurów korali ${ }^{54}$.

O wszystkich pracach prowadzonych przy sanktuarium z uznaniem mówił kard. Stefan Wyszyński podczas wizytacji kanonicznej odbytej w dniach 18-19 sierpnia 1973 r. W Księdze wizytacji napisał:

Przybywam tu, jako pielgrzym, aby uczcić łaskami słynący od wieków obraz Matki Bożej Lewiczyńskiej. Ponieważ obraz nie był koronowany, proszę o przygotowanie wniosku do Stolicy Świętej o historycznym charakterze. Wniosek ten chciałbym zabrać do Rzymu w listopadzie bieżącego roku i tam osobiście będę się starał o zezwolenie ${ }^{55}$.

Zgodnie z sugestią, na początku października 1973 roku, ks. Makowski złożył w sekretariacie prymasa Polski wspomniane pismo, wraz z thumaczeniem na łacinę „Opisu historycznego o kulcie, starożytności i wartości artystycznej obrazu”56. W styczniu 1974 r., podczas audiencji u metropolity, kustosz został zobligowany przez niego do rozpoczęcia przygotowań koronacyjnych, które miały odbyć się w tymże roku. Jednak dopiero 14 grudnia 1974 r. ks. Makowski ogłosił publicznie, że koronacja odbędzie się 10 sierpnia 1975 r. Bulla koronacyjna papieża Pawła VI, została wydana 8 października 1974 r. W imieniu papieża korony na skronie Pana Jezusa i Matki Bożej w lewiczyńskim wizerunku miał nałożyć kard. Stefan Wyszyński.

W związku z przygotowaniami do koronacji zintensyfikowane zostały prace budowlane. Od kwietnia do czerwca 1974 r. poddano gruntownemu remontowi kamienne ogrodzenie wokół kościoła, wylano beton przed schodami głównymi i bocznymi prowadzącymi do świątyni. Pozłocono ołtarz główny i zgodnie z sugestią wizytatora, zamontowano w kościele dwa nowe reflektory oświetlające cudowny obraz ${ }^{57}$. Przygotowano także miejsce i drewno potrzebne do budowy ołtarza polowego. Na plac koronacyjny wybrano, przylegający do wzgórza świątynnego, teren ogrodu parafialnego. W grudniu $1974 \mathrm{r}$. zdjęto z cudownego obrazu korony, które miały powrócić na swoje miejsce w dniu koronacji. Na potrzeby uroczystości dokonano również remontu starej plebanii oraz sali katechetycznej, w której miano przyjąć przybyłe na uroczystości osoby duchowne ${ }^{58}$.

${ }^{53}$ APL 26, Księga Fundi inscripti Parafii Lewiczyn od 1945 roku, s. 20; Kiełbowska, Parafia Lewiczyn, s.121-122.

${ }^{54}$ Kiełbowska, Parafia Lewiczyn, s. 121-123.

${ }^{55}$ APL 54/1, Księga wizytacji, s. 122.

${ }^{56}$ Tamże, s. 57; APL 54/1, Księga wizytacji, s. 121-129.

${ }^{57}$ APL 41/1, Kronika parafialna 1945-1980, s. 59-60.

${ }^{58}$ Tamże, s. 61. 
Przez cały rok przybywali do sanktuarium pielgrzymi, by uzyskać odpust w roku jubileuszowym $1974^{59}$. Szczególnie liczne były pielgrzymki w 1. i 2. dzień Zielonych Świąt oraz na uroczystość Wniebowzięcia NMP.

Rok 1975 był apogeum prac przygotowujących do koronacji. W lutym sprowadzono organy elektryczne, które miały uświetnić uroczystości. W marcu rozesłano zaproszenia na koronację do biskupów. O mającej się odbyć koronacji, ks. Makowski informował przybywających pielgrzymów. Kuria Metropolitalna w Warszawie wydała specjalny komunikat o uroczystościach koronacyjnych, z poleceniem ogłoszenia go z ambon w kościołach całej archidiecezji, z prośbą aby zachęcić wiernych do udziału $\mathrm{w}$ uroczystościach ${ }^{60}$. Wykonano również plakaty z informacją o koronacji, które rozwieszono w parafiach sąsiednich dekanatów ${ }^{61}$. W maju pozłocono wszystkie ołtarze w kościele i uporządkowano teren wokół sanktuarium. Sprowadzono, przygotowaną specjalne na uroczystości koronacyjne, świecę wotywną. W lipcu wzniesiono podium, służące jako podstawa ołtarza, na którym miała się odbyć koronacja. W prace przygotowawcze włączyła się cała parafia. W każdą niedzielę kustosz dziękował pomagającym i wyczytywał ich listę C2. $^{62}$

Na koronację obrazu Matki Bożej, wszystkie domy w parafii zostały udekorowane jej wizerunkiem, a drogi prowadzące do Lewiczyna i sanktuarium - wstążkami w barwach narodowych, kościelnych i maryjnych. Wzniesiono także bramy powitalne, prowadzące na teren sanktuarium ${ }^{63}$.

Początkiem uroczystości koronacyjnych w Lewiczynie było całonocne czuwanie maryjne, rozpoczęte w nocy 9 sierpnia. Modlitewnemu zebraniu przewodniczył ks. Władysław Petecki, proboszcz sąsiedniej parafii Goszczyn. Następnego dnia, w uroczystej procesji z asystą duchowieństwa i wiernych, której przewodniczył bp Zbigniew Kraszewski, przeniesiono ze świątyni cudowny obraz Matki Bożej na plac koronacyjny. Za orszakiem z obrazem Matki Bożej podążyli biskupi zaproszeni na uroczystości, ostatni szli: celebrans i współkoronator kard. Karol Wojtyła - metropolita krakowski oraz prymas S. Wyszyński. Towarzyszył im i uczestniczył w koronacji także bp Marian Przykucki, sufragan poznański. Było to nawiązanie do początków lewiczyńskiego sanktuarium, gdyż do rozbiorów znajdowało się ono w ówczesnej diecezji poznańskiej. Podczas procesji 30. osobowa orkiestra ze Żdżar grała intradę (uroczystą fanfarę). W kazaniu prymas S. Wyszyński zwrócił uwagę na temat godności pracy na roli i na szacunek, jakim powinien cieszyć się rolnik za swoją ciężką pracę.

Po homilii nastąpił akt koronacji. Odczytano tekst bulli koronacyjnej papieża Pawła VI, po czym metropolita poświęcił korony. Do uczestniczenia w akcie koronacji zaproszono kard. Wojtyłę i bp. Przykuckiego. W momencie nałożenia

${ }^{59}$ APL 54/1, Księga wizytacji, s. 130.

${ }^{60}$ Odezwa do wiernych archidiecezji warszawskiej przed uroczystościami koronacyjnymi w Lewiczynie i Głogowie, „Wiadomości Archidiecezjalne Warszawskie”, 7 (1975) s. 340-342.

${ }^{61}$ Kiełbowska, Parafia Lewiczyn, s. 128.

${ }^{62}$ Tamże, s. 128-129.

${ }^{63}$ APL 41/1, Kronika parafialna 1945-1980, s. 61-62. 
koron zabrzmiała intrada, po której odśpiewano uroczyste Te Deum ${ }^{64}$. Pod koniec celebracji liturgicznych ks. Makowski podziękował kardynałom: Wyszyńskiemu i Wojtyle oraz biskupowi Przykuckiemu za dokonanie koronacji cudownego obrazu Matki Bożej. Ze szczególnym słowami podziękowania zwrócił się ks. Makowski do ks. Józefa Zawitkowskiego za „pomoc organizatorską" ${ }^{65}$ oraz parafianom za wszelkie prace w przygotowaniu uroczystości koronacyjnych. Słowa wdzięczności za obecność usłyszeli także pielgrzymi, którzy trwali na modlitwie pomimo nieznośnego upału. Na zakończenie zgromadzonym uczestnikom uroczystości koronacyjnych prymas udzielił papieskiego błogosławieństwa ${ }^{66}$.

Po zakończeniu uroczyści przy ołtarzu polowym cudowny obraz Matki Bożej został zaniesiony do kościoła $\mathrm{w}$ procesji, $\mathrm{w}$ asyście duchowieństwa oraz wiernych. Gdy wizerunek ustawiono na ołtarzu, chór z Warki zaintonował uroczyste Gaude Mater Polonia. Wierni, modląc się w skupieniu i milczeniu, na kolanach okrążali ołtarz z cudownym obrazem. Po mszy odbył się także koncert piosenek religijnych w wykonaniu zespołów młodzieżowych.

Darem dla Matki Bożej Lewiczyńskiej z okazji koronacji, złożonym przez prymasa Wyszyńskiego, był biały ornat ${ }^{67}$. Ustalono, że rocznica koronacji w sanktuarium będzie obchodzona $\mathrm{w}$ dzień głównego odpustu - 15 sierpnia ${ }^{68}$. W następnym roku biskupi uczestniczący w uroczystości koronacji cudownego obrazu otrzymali od księdza kustosza i wdzięcznych parafian pamiątki: obrazy Matki Bożej Lewiczyńskiej i albumy ze zdjęciami z koronacji ${ }^{69}$. W listopadzie 1976 r. list z podziękowaniami za pamiątki z koronacji przesłał na ręce ks. Jana Makowskiego metropolita krakowski Karol Wojtyła. Pisał w nim:

Czcigodny i Drogi Księże Proboszczu, otrzymałem w dniu dzisiejszym cenny dar w postaci Obrazu Matki Bożej i albumu z koronacji w Lewiczynie. Serdecznie dziękuję za te cenne dary i pamiątki i jeszcze raz zapewniam, że z radością uczestniczyłem w tych uroczystościach. Prosząc o modlitewną pamięć, łączę kapłańskie pozdrowienie i szczęść Boże w pracy duszpasterskiej ${ }^{70}$.

W uroczystościach koronacyjnych w Lewiczynie wzięło udział 14 biskupów i około 500 duchownych, także z Czechosłowacji, Szwecji i Ameryki Południo$w^{j}{ }^{71}$. Licznie reprezentowane były zgromadzenia zakonne żeńskie i męskie. Według relacji ks. Makowskiego, w uroczystościach wzięło udział około 50.000 pątników ${ }^{72}$. Nakręcono także krótki film z koronacji obrazu Matki Bożej ${ }^{73}$.

Koronacja obrazu Matki Bożej i ogłoszenie jej Panią Ziemi Grójeckiej stały

${ }^{64}$ APL 41/1 Kronika parafialna 1945-1980, s. 63.

${ }^{65}$ Tamże, s. 64.

${ }^{66}$ Tamże, s. 64; „Wiadomości archidiecezjalne warszawskie”, 9 (1975) s. 544-546.

${ }^{67}$ Kiełbowska, Parafia Lewiczyn, s. 130.

${ }^{68}$ APL 41/1 Kronika parafialna 1945-1980, s. 68.

${ }^{69}$ Tamże, s. 67; Kiełbowska, Parafia Lewiczyn, s. 130.

${ }^{70}$ Cyt. za: Kiełbowska, Parafia Lewiczyn, s. 130.

${ }^{71}$ Tamże, s. 63; Z. Kiełbowska, Parafia Lewiczyn, s. 130; Z dawna Polski Tyś Królowa. Przewodnik po sanktuariach maryjnych, wyd. 5, popr. i uzup., Szymanów 1999, s. 374-376.

${ }^{72}$ APL 41/1 Kronika parafialna 1945-1980, s. 63.

${ }^{73}$ Tamże, s. 67. 
się bodźcem do szerzenia kultu cudownego obrazu. Bardzo uroczyście obchodzono w Lewiczynie pierwszą rocznicę koronacji cudownego obrazu - 15 sierpnia 1976 r. Uroczystościom przewodniczył bp pomocniczy archidiecezji warszawskiej Jerzy Modzelewski, a kazanie okolicznościowe wygłosił dziekan grójecki ks. Ryszard Oksiński. Kopie obrazu Matki Bożej zostały przekazane parafiom w dekanacie grójeckim oraz księżom dziekanom dla parafii w dekanatach: bielskim, goszczyńskim i wareckim ${ }^{74}$. W czasie kolędy w 1976 r. księża rozdawali wiernym obrazki z wizerunkiem Matki Bożej Lewiczyńskiej ${ }^{75}$. Rozpoczęto także przygotowania do peregrynacji obrazu w dekanacie grójeckim. Na potrzeby planowanych uroczystości pozłocono fragmenty sukienki na kopii cudownego obrazu. Dla potrzeb nawiedzenia wykonano również kopię filmu o koronacji oraz przezrocza dotyczące lewiczyńskiego sanktuarium, prezentowane wiernym w parafiach, które odwiedzał obraz Matki Bożej ${ }^{76}$.

Pierwszą parafią, nawiedzoną w dniach od 30 września do 3 października 1976 r. przez lewiczyński wizerunek, był Grójec. Dnia 30 września do Lewiczyna przybyła kilkuosobowa delegacja grójeckich parafian po obraz. Przyozdobiony kwiatami samochód-kaplica zabrał kopię nawiedzenia do kościoła parafialnego pw. św. Mikołaja, gdzie oczekiwali licznie zebrani parafianie, ks. dziekan Ryszard Okiński i bp Jerzy Modzelewski oraz kapłanami dekanatu grójeckiego ${ }^{77}$.

Po uroczystym wprowadzeniu przez bramy powitalne obraz zajął miejsce w centrum ołtarza głównego. W trakcie trzydniowego nawiedzenia dziekan Okiński zorganizował 29 nabożeństw, a kazania okolicznościowe głosił ks. J. Zawitkowski. Na zakończenie nawiedzenia, 3 października, odbyła się procesja różańcowa z obrazem Matki Bożej. Po jej zakończeniu wizerunek powrócił do lewiczyńskiego sanktuarium ${ }^{78}$.

W roku 1976 obraz nawiedził parafie w Grójcu, Rembertowie (24-26 października), Promnej (18-21 listopada), Worowie (2-5 grudnia), Przybyszewie (5-8 grudnia), Tarczynie (5-8 grudnia) oraz Lubani (8-12 grudnia) ${ }^{79}$.

W nawiedzeniach parafii w Przybyszewie i Lubani uczestniczył cudowny obraz, pozostałe miejscowości nawiedziła kopia. W peregrynacji obrazu na zaproszenie proboszczów brali udział i przewodniczyli uroczystościom biskupi. W czterech parafiach nawiedzanych przez obraz Matki Bożej był bp Władysław Miziołek, natomiast w pozostałych biskupi Jerzy Modzelewski i Zbigniew Kraszewski. Do wygłoszenia okolicznościowych nauk w niektórych nawiedzanych parafiach proboszczowie zaprosili ks. Józefa Zawitkowskiego. Ks. Makowski, często uczestniczył w peregrynacji wizerunku, udzielał informacji o sanktuarium w Lewiczynie i zachęcał do jego odwiedzania. Obraz nawiedził wybrane parafie dekanatu grójeckiego, mogielnickiego, tarczyńskiego, wareckiego ${ }^{80}$.

\footnotetext{
${ }^{74}$ APL 54/1 Księga wizytacji, s. 133; Matyjas, Smak XX wieku, s. 247.

${ }^{75}$ Tamże, s. 134.

${ }^{76}$ APL 41/1 Kronika parafialna 1945-1980, s. 68.

${ }^{77}$ Tamże, s. 69

${ }^{78}$ Tamże, s. 69; Matyjas, Z dziejów Grójecczyzny, s. 84; Kiełbowska, Parafia Lewiczyn, s. 133.

${ }^{79}$ APL 41/1 Kronika parafialna 1945-1980, s. 69-72; Kiełbowska, Parafia Lewiczyn, s. 133.

${ }^{80}$ APL 41/1 Kronika parafialna 1945-1980, s. 69-72.
} 
Peregrynacja lewiczyńskiego obrazu trwała również w 1977 r. W sumie we wspomnianym roku obraz był w 22 parafiach dekanatów: grójeckiego, konstancińskiego, czerskiego, tarczyńskiego, wareckiego, nowomiejskiego, białorawskiego i mogielnickiego ${ }^{81}$. W dniach 1-3 maja obraz był w parafii Zbrosza Duża. Jej proboszcz, ks. Czesław Sadłowski, dziękował Matce Bożej za „pokonanie wielu trudności i cierpień” przy tworzeniu parafii i budowie miejscowej świątyni ${ }^{82}$.

Obok szerzenia kultu cudownego obrazu ks. Makowski podejmował różne działania mające na celu rozwój ośrodka kultowego. W 1977 r. w uroczystość Matki Kościoła dziekan ks. Ryszard Okiński poświęcił plac w ogrodzie parafialnym, gdzie ustawiono drewniane kapliczki. W zamyśle księdza kustosza miały być to dróżki Matki Bożej, gdzie pielgrzymi rozważaliby tajemnice różańcowe. Wtedy też poświęcono znajdującą się w sąsiedztwie świątyni płaskorzeźbę w kamieniu z wizerunkiem Matki Bożej Lewiczyńskiej w sukience i koronach ${ }^{83}$.

W samym kościele poprawiono chodnik za ołtarzem Matki Bożej, który pielgrzymi przemierzają na klęczkach, modląc się w różnych intencjach. Obok ołtarza Matki Bożej zawieszono różaniec - dar ks. Kazimierza Romaniuka, ówczesnego rektora Wyższego Metropolitalnego Seminarium Duchownego w Warszawie ${ }^{84}$.

Ks. Makowski chciał przy sanktuarium utworzyć ośrodek dla pielgrzymów przybywających do Lewiczyna oraz zaadaptować budynek starej plebanii na muzeum, w którym gromadzone będą pamiątki związane z kultem Matki Bożej Lewiczyńskiej. Chciał stworzyć prężny ośrodek maryjny, promieniujący na ziemię grójecką i południową część archidiecezji warszawskiej ${ }^{85}$, jednak z dniem 27 czerwca 1977 r. został proboszczem parafii w Białej Rawskiej.

Następcą ks. Makowskiego został ks. Stanisław Dusiło, pełniący dotychczas funkcję rektora w kościele w Guzowie ${ }^{86}$. Głównym zadaniem nowego kustosza było kontynuowanie prac remontowych, zwłaszcza że po ulewach w końcu sierpnia na ścianach kościoła zaczęły pojawiać się zacieki ${ }^{87}$. W marcu 1978 r. zaczęto zbierać pieniądze na remont w miejscowościach należących do parafii. Stopniowo rozpoczęto też gromadzenie potrzebnych materiałów. Blachę miedzianą sprowadzono z huty Imielin na Śląsku. Jej transport dotarł do Lewiczyna 27 maja 1979 r. Budulec modrzewiowy, potrzebny przy pracach budowlanych, sprowadzono 17 stycznia 1980 r. Drewno pocięto i obrobiono w tartaku w Białobrzegach ${ }^{88}$. Remont rozpoczął się 8 kwietnia, zaraz po Wielkanocy. Pracę rozpoczęto od wieży kościelnej i fundamentów. Odkopano fundamenty i wzmocnione je wewnątrz i z zewnątrz. Oszalowano nowymi deskami dolną część wieży oraz położono

\footnotetext{
${ }^{81}$ Tamże, s. 72-102.

82 Tamże, s. 74.

${ }^{83}$ Tamże, s. 73-78; APL 54/1 Księga wizytacji, s. 141.

${ }^{84}$ 41/1 Kronika parafialna 1945-1980, s. 78-79.

${ }^{85}$ APL 54/1 Księga wizytacji, s. 134-135.

${ }^{86}$ Ks. Stanisław Dusiło urodził się 11 września 1935 r. Święcenia kapłańskie przyjął 26 maja 1963 r. w Warszawie z rąk kard. S. Wyszyńskiego; por. też APL 41/1 Kronika parafialna 1945-1980,

${ }^{87}$ Tamże, s. 87.

${ }^{88}$ Kiełbowska, Parafia Lewiczyn w latach 1945-1995, s. 65.
} s. 80. 
nową podłogę i strop. Prace ukończono przed odpustem na uroczystość Matki Kościoła ${ }^{89}$. Z powodów problemów finansowych, ks. Dusiło po konsultacji z Radą Parafialną, postanowił przeprowadzić kwestę w sąsiednich parafiach dekanatu grójeckiego. Także dochód z loterii przeprowadzonej 15 sierpnia $1980 \mathrm{r}$. pozwolił na dokończenie prac remontowych przy kruchcie i wieży kościelnej. Ostatecznie rozebrano starą wieżę, a na jej miejscu wzniesiono nową, liczącą 32 metry wysokości. Na nowej wieży i kruchcie ułożono blachę miedzianą ${ }^{90}$.

Drugi etap prac przy remoncie rozpoczął się w pod koniec maja 1983 r., a prace prowadziła ekipa budowlana górali z Zakopanego. Najpierw zerwano stare oszalowanie z desek. Przy dalszych pracach remontowych od strony południowej kościoła odsłonięto pierwotne wejście do świątyni, nad którym widniał napis informujący o dacie budowy kościoła: „A. D. 1604”, Początkowo ks. Dusiło myślał o przywróceniu tego wejścia, ale z powodu trudności z wkomponowaniem go w bryłę świątyni, zostało powtórnie oszalowane ${ }^{91}$. W trakcie prac przy ścianach prezbiterium wykonano kapliczkę na obraz Matki Bożej, który namalowała S. Lewandowska z Kuss. Wymieniono więźbę, a dach kościoła, podwyższony o dwa metry, pokryto blachą miedzianą. Usunięto z niego również sygnaturkę, pozostawiwszy tylko krzyż na złotej kuli. Rozebrano również starą, przylegającą do kościoła zakrystię i wzniesiono nową w stylu zakopiańskim ${ }^{92}$. W czasie prac renowacyjnych wymieniono także całą instalację elektryczną z $1962 \mathrm{r}$.

Ks. Dusiło, dbając o rozwój kultu Matki Bożej w parafii, zainicjował specjalne przygotowania do odpustu z okazji Wniebowzięcia NMP. Mieszkańcy poszczególnych miejscowości przybywali do sanktuarium w pielgrzymkach, na trzy dni przed odpustem. Uczestniczyli we mszy świętej z nauką i mogli wyspowiadać się. Po nabożeństwie obchodzili na kolanach wielki ołtarz z cudownym obrazem ${ }^{93}$.

Innym elementem szerzenia kultu było nawiedzenie obrazu Matki Bożej i Ewangelii w rodzinach parafii. Trwało ono od 31 grudnia 1978 do 11 kwietnia 1980 r. Na zakończenie nawiedzenia w każdej miejscowości odprawiano mszę św. Obecność wizerunku w rodzinach sprawiła nowe ożywienie, składano więcej podziękowań Matce Bożej za otrzymane łaski ${ }^{94}$. Wierni zamawiali również msze św. przed obrazem Matki Bożej. W sumie od 10 lipca do 31 grudnia 1977 r. ks. Dusiło odprawił 95 wotywnych mszy św. ${ }^{95}$

Bardzo uroczyście obchodzono w 1980 r. piątą rocznicę koronacji cudownego wizerunku. Mszy św. przewodniczył bp Władysław Miziołek, który przypomniał wiernym, że był uczestnikiem uroczystości koronacyjnych w 1975 r. Zauważył, że koronacja, a potem nawiedzenie wielu miejscowości przez obraz Matki Bożej Lewiczyńskiej, wpłynęły na rozszerzenie kultu, o czym świadczy liczba

\footnotetext{
${ }^{89}$ APL 41/1 Kronika parafialna 1945-1980, s. 149.

${ }^{90}$ APL 42/2 Kronika parafialna 1980-2012, s. 29; Kiełbowska, Parafia Lewiczyn, s. 66.

${ }^{91}$ APL 42/2 Kronika parafialna 1980-2012, s. 30.

${ }^{92}$ Tamże, s. 31-32.

${ }^{93}$ Tamże, s. 5.

${ }^{94}$ Kiełbowska, Parafia Lewiczyn, s. 135.

${ }^{95}$ APL 49, Księga pamiątkowa 1966, s. 2; Kiełbowska, Parafia Lewiczyn, s. 136.
} 
pielgrzymów na uroczystościach odpustowych ${ }^{96}$. Podczas wizytacji kanonicznej, bp W. Miziołek zwrócił też uwagę proboszczowi, aby zwiększył liczbę kół Żywego Różańca, który grupował by także dzieci i młodzież.

Na pięciolecie koronacji, w roku 1980, ks. Dusiło dokonał inwentaryzacji wotów w sanktuarium. Każdy egzemplarz zostal opatrzony w spisie numerem porządkowym. Tam, gdzie było to możliwe, podano dokładną datę, imiona i nazwiska ofiarodawców. Inwentarz znajduje się na kartach kroniki parafialnej, obok spisu umieszczono także obrysy niektórych wotów. Według inwentarza, w sanktuarium znajdowały się 94 wota: srebrne, pozłacane, posrebrzane, w kształcie serduszek, plakietek wotywnych z przedstawieniami oczu, uszu, rąk, nóg. Obok nich znajdowały się odznaczenia wojskowe i państwowe ${ }^{97}$.

We wrześniu 1981 r. dróżki Matki Bożej, których pomysłodawcą był ks. Makowski, zostały przeniesione z terenu ogrodu parafialnego na plac wokół kościoła. Ks. Dusiło wspominał, że zmiana lokalizacji kapliczek spotkała się ze zrozumieniem i pochwała parafian. Na odpust Narodzenia NMP (MB Siewnej) -8 września, kapliczki zostały przybrane kwiatami ${ }^{98}$.

W dniach 11-18 października obraz Matki Bożej Lewiczyńskiej po raz kolejny gościł w Grójcu w związku z odbywającymi się tam misjami parafialnymi. Na ich zakończenie, ks. Dusiło odprawił mszę św.

W niedzielę 13 grudnia 1981 r. władze komunistyczne wprowadziły stan wojenny w Polsce. Tego samego dnia w godzinach wieczornych prymas Józef Glemp wystąpił z apelem o powstrzymanie się od rozlewu krwi ${ }^{99}$. W Lewiczynie trwały wówczas rekolekcje adwentowe, a po każdej mszy św. kapłani, ministranci oraz wierni, obchodzili na kolanach ołtarz z cudownym obrazem NMP w intencji, aby nie doszło w Polsce do bratobójczych walk i rozlewu krwi ${ }^{100}$.

Dnia 5 stycznia, w odpowiedzi na prośbę prymasa Glempa, odbyło się specjalne nabożeństwo w intencji Ojczyzny. Podobne nabożeństwa odbyły się we wszystkich sanktuariach archidiecezji warszawskiej. Mimo stanu wojennego, przybyły do Lewiczyna delegacje ze wszystkich parafii dekanatu grójeckiego. Mszę św. koncelebrowali przybyli na nabożeństwo kapłani, na czele z dziekanem grójeckim, ks. Ryszardem Okińskim. Po zakończeniu liturgii, duchowni i wierni szczelnie wypełniający tego dnia kościół obeszli na kolanach ołtarz z obrazem Matki Bożej ${ }^{101}$.

W sierpniu 1982 r. pielgrzymi thumnie uczestniczyli w uroczystościach, które odbyły się w sanktuarium lewiczyńskim z okazji 600-lecia obecności obrazu jasnogórskiego w Polsce. Pielgrzymki z Wilkowa, Drwalewa, Jeziórki i Belska Dużego przybyły 24 sierpnia. Następnego dnia przybyła grupa z Grójca. W samą uroczystość, 26 sierpnia po sumie, wyruszyła procesja wokół kościoła do sześciu ołtarzy symbolizujących liczbę wieków obecności obrazu na Jasnej Górze ${ }^{102}$.

\footnotetext{
${ }^{96}$ APL 54/1 Księga wizytacji, s. 156-160.

${ }^{97}$ APL 41/1 Kronika parafialna 1945-1980, s. 150-153.

${ }^{98}$ APL 42/2 Kronika parafialna 1980-2012, s. 6.

${ }^{99}$ W. Roszkowski, Historia Polski 1914-2005, Warszawa 2009, s. 377.

${ }^{100}$ APL 42/2 Kronika parafialna 1980-2012, s. 14.

${ }^{101}$ APL 42/2 Kronika parafialna 1980-2012, s. 17-18.

102 Tamże, s. 24.
} 
Odpust 15 sierpnia był rozpoczęciem przygotowań do uroczystości 300-lecia ogłoszenia cudownym obrazu Matki Bożej. Ponownie, jak w latach poprzednich przybyły liczne grupy pątnicze ze wszystkich stron ziemi grójeckiej ${ }^{103}$.

Przy okazji uroczystości odpustowych w 1983 r. rozprowadzano wśród pielgrzymów wybite w Warszawie medaliki z wizerunkiem Matki Bożej Lewiczyńskiej $^{104}$.

W dniu 12 listopada odbyły się w sanktuarium uroczystości związane z Rokiem Świętym - 1950 lat od śmierci Jezusa Chrystusa. Uroczystościom przewodniczył bp Zygmunt Kraszewski z Warszawy. Tego dnia do sanktuarium przybyli pielgrzymi z dwóch dekanatów: grójeckiego i goszczyńskiego. W uroczystościach wzięło udział 30 kapłanów oraz rzesze wiernych. Decyzją prymasa Glempa, kościół w Lewiczynie był świątynią jubileuszową, co wzmogło jeszcze napływ pielgrzymów. Sanktuarium już raz pełniło rolę świątyni jubileuszowej w 1975 r., Z woli ks. prymasa S. Wyszyńskiego ${ }^{105}$.

Ks. Dusiło chciał w Lewiczynie rozwinąć ruch oazowy, stworzony przez księdza Franciszka Blachnickiego na bazie doświadczeń związanych z pracą ze służbą liturgiczną ${ }^{106}$. Do odwiedzenia sanktuarium zapraszał więc grupy oazowe, które mogły tu odbyć rekolekcje, dni skupienia itp. W dniach od 27 stycznia do 1 lutego 1984 roku odbyła się w Lewiczynie Oaza Rekolekcyjna Animatorów (ORA). Rekolekcje prowadził ks. Jan Szymborski z Warszawy. W dniach od 1 do 6 lutego odbywał się II turnus, a nauki prowadził ks. Dusiłoo ${ }^{107}$. Na początku 1985 roku grupa animatorów oazowych przeżywała swój dzień skupienia. Moderatorem był ks. Jan Pietrzyk ${ }^{108}$.

W kwietniu tego samego roku zorganizowano w Lewiczynie nabożeństwo dla młodzieży, z okazji roku jubileuszowego. Brało w nim udział ok. 500 osób, a spotkaniu przewodniczył dziekan ks. Ryszard Okiński ${ }^{109}$.

W dniach 19-27 maja obraz Matki Bożej nawiedził parafię w Wilkowie, a od 27 maja - 3 czerwca, w Błędowie, gdzie odbywały się misje parafialne. ${ }^{110}$

W 1984 r. obchodzono w Lewiczynie potrójną rocznicę: 380 lat istnienia modrzewiowej świątyni, 380 lat obecności obrazu Matki Bożej w Lewiczynie oraz 300 lat od ogłoszenia przez władze kościelne owego wizerunku cudownym. Uroczystości jubileuszowe rozpoczęły się w 10 czerwca 1984 r. Na uroczystości przybyły pielgrzymki z Goszczyna oraz Mogielnicy. Czterema autokarami przybyła pielgrzymka z parafii w Płudach, którą wcześniej nawiedziła kopia cudownego obrazu w 35-lecie jej powstania ${ }^{111}$.

\footnotetext{
${ }^{103}$ Tamże, s. 25.

104 Tamże, s. 37.

${ }^{105}$ Tamże, s. 41-43; APL 49, Księga pamiątkowa 1966, s. 58-59.

${ }_{106}$ R. Derewenda, Dzieło Wiary. Historia Ruchu Światło-Życie 1950-1985, Kraków 2010,

${ }^{107}$ APL 42/2 Kronika parafialna 1980-2012, s. 45; APL 49, Księga Pamiątkowa 1966, s. 60-63.

${ }^{108}$ APL 49, Księga pamiątkowa 1966, s. 75.

${ }^{109}$ APL 42/2 Kronika parafialna 1980-2012, s. 46.

110 Tamże, s. 46.

${ }^{111}$ Tamże, s. 47-48; APL 49, Księga pamiątkowa 1966, s. 65.
} s. 17-26. 
Bardzo uroczyście obchodzono odpust w dniu 15 sierpnia, upamiętniający trzechsetlecie ogłoszenia dekretu bp Wierzbowskiego o cudowności obrazu lewiczyńskiego. Swoją obecnością obchody uświetnił i przewodniczył sumie odpustowej bp Władysław Miziołek, sprawujący ją wraz z duchownymi dekanatu grójeckiego, którzy przybyli na czele pielgrzymek ze swoich parafii. Również odpust w święto Narodzenia NMP, zgromadził dużo większą liczbę wiernych niż w latach poprzednich ${ }^{112}$.

W dniu 7 października obraz Matki Bożej nawiedził parafię w Grójcu. Wizerunek niesiono podczas procesji różańcowej do pięciu ołtarzy ulokowanych wokół kościoła parafialnego. Wieczorem został odwieziony do Lewiczyna przez grupę grójeckich parafian ${ }^{113}$.

W 1984 r. ks. Dusiło, wybudował dom pielgrzymkowo-ewangelizacyjny, który odtąd służył przybywającym do sanktuarium pielgrzymom i grupom oazowym. $\mathrm{Na}$ dole znajdowały się pomieszczenia gospodarcze i duża sala spotkań, na górze natomiast pięć pokoi sypialnych ${ }^{114}$.

W 1985 r. wszystko było podporządkowane uroczystościom 10 rocznicy koronacji cudownego obrazu Matki Bożej. Na wiosnę parafianie uporządkowali teren wokół kościoła i teren cmentarza przykościelnego. W dniach 7-9 sierpnia odbyło się Triduum przygotowujące parafian oraz pielgrzymów do uroczystości, była możliwość spowiedzi oraz udziału we mszy świętej. Przed obchodami rocznicy trasy prowadzące do świątyni zostały przyozdobione flagami i kokardami. Wzniesiono także bramy z napisami powitalnymi ${ }^{115}$. W późnych godzinach popołudniowych mszę św. sprawowaną na ołtarzu polowym odprawił i wygłosił homilie prymas J. Glemp. Na zakończenie uroczystości, poświęcono Dom Ewangelizacyjny imienia Jana Pawła II ${ }^{116}$. W uroczystości wzięło również udział 43 kapłanów ${ }^{117}$.

W nocy z 22 na 23 listopada odbyło się w lewiczyńskim sanktuarium czuwanie modlitewne duchowieństwa i wiernych dekanatu grójeckiego w intencji Synodu Biskupów odbywającego się w Rzymie. Odbyło się wystawienie Najświętszego Sakramentu, odmówiono różaniec, a następnie odprawiono mszę wotywną do Matki Bożej, po której zakończeniu odbyła się Droga Krzyżowa. Nabożeństwo zakończono godzinkami, po których uroczyście zasłonięto cudowny obraz ${ }^{118}$.

Z dniem 16 lutego 1986 roku prymas J.Glemp zwolnił z funkcji kustosza sanktuarium i proboszcza w Lewiczynie ks. S. Dusiło, mianując na jego miejsce ks. Grzegorza Krysztofika ${ }^{119}$.

${ }^{112}$ APL 42/2 Kronika parafialna 1980-2012, s. 53-54; APL 49, Księga pamiątkowa 1966, s. $66-67$.

${ }^{113}$ APL 42/2 Kronika parafialna 1980-2012, s. 56; APL 49, Księga pamiątkowa 1966, s. 68.

${ }^{114}$ APL 55/2 Księga wizytacji parafii Lewiczyn, s. 8-9.

${ }^{115}$ APL 42/2 Kronika parafialna 1980-2012, s. 69.

116 Tamże, s. 70.

117 Tamże, s. 70-71.

${ }^{118}$ Kiełbowska, Parafia Lewiczyn, s. 31.

${ }^{119}$ APL 42/2 Kronika parafialna 1980-2012, s. 75. Ks. Dusiło został skierowany do Domaniewic. Doświadczenie nabyte w Lewiczynie pomogło mu w przygotowaniu do koronacji znajdującego się tam łaskami słynącego obrazu Matki Bożej, zob. tamże, s. 75. 
W dniu 2 marca 1986 r. ${ }^{120}$ został on oficjalnie przedstawiony podczas sumy swoim nowym parafianom przez dziekana grójeckiego ks. Stanisława Laskowskiego. Wprowadzony w tok bieżących spraw z życia parafii i sanktuarium, zabrał się z niezwykłą energią do rozpoczętych przez poprzednika prac remontowych. Uporządkowano wówczas teren wokół kościoła. Aby wzmocnić skarpę kościelną, od strony południowo-wschodniej nawieziono 100 przyczep ziemi i kamieni. Rozpoczęto też prace remontowe w kościele; do czerwca 1987 r. udało się wymienić okna w świątyni na nowe, metalowe, otwierane i okratowane. Poddano konserwacji znajdujące się w oknach witraże. Dokonano reorganizacji prezbiterium, wykonano modrzewiowe schody i podłogę, odnowiono ołtarz główny ${ }^{121}$. Po wzmocnieniu i poszerzeniu skarpy, wokół świątyni postawiono maszty, na których zawieszono oświetlające kościół lampy sodowe. Zakupiono i przygotowano drzewo modrzewiowe, które miało być wykorzystane w trakcie dalszych prac remontowych przy świątyni ${ }^{122}$.

W czasie dalszych prac remontowych w latach 1987-1989 zaszły zmiany w wyglądzie wnętrza świątyni - usunięto z kościoła dwa ołtarze boczne, znajdujące się w narożach nawy kościoła, w których znajdowały się obrazy Niepokalanego Poczęcia NMP oraz św. Antoniego. Obecnie znajdują się one na północnej ścianie świątyni. W czasie trwania remontu tabernakulum zostało opancerzone, a następnie przeniesione z ołtarza głównego do ołtarza z rzeźbą Chrystusa na krzyżu, przestawionego ze ściany południowej na północną kościoła, a znajdującą się na ścianie północnej świątyni ambonę przeniesiono w miejsce ołtarza Chrystusa Ukrzyżowanego ${ }^{123}$.

Z myślą o bezpieczeństwie znajdujących się w świątyni dzieł sztuki i cennych przedmiotów, zamontowano w niej w 1988 r. system alarmowy. W późniejszym okresie zakupiono nowe ławki. Do 1991 r. przeprowadzono także rekonstrukcję sklepienia stropu świątyni. Została przywrócona, zlikwidowana w 1986 r. belka tęczowa, a na nowym suficie wykonano kasetony ${ }^{124}$. Kustosz planował również generalną konserwację obu ołtarzy znajdujących się w kościele ${ }^{125}$.

Prace budowlane trwały także przy domu rekolekcyjnym. Ks. Krysztofik uważał, że należy go powiększyć, by mógł służyć coraz liczniej przybywającym do Lewiczyna pielgrzymom oraz różnym grupom młodzieży oazowej. W dobudowanej w 1989 r. części miały znaleźć się pomieszczenia sanitarne oraz kuchnia. Pomyślano także o mieszkaniu dla drugiego kapłana, który miałby służyć kusto-

${ }^{120}$ Ks. Krysztofik urodził się w Cegielni Krośnie k. Brwinowa 18 marca 1948 r. Święcenia kapłańskie przyjął 6 czerwca 1971 r. Przed objęciem lewiczyńskiej parafii był proboszczem w Guzowie. Dotychczasowy proboszcz, ks. S. Dusiło, odchodząc z Lewiczyna, charakteryzował swego następcę jako gorliwego kapłana, rozmiłowanego w liturgii i dbałego o jej piękno. Miał również kontynuować rozpoczęte w sanktuarium prace remontowe; por. APL 42/2 Kronika parafialna 19802012, s. 80-81.

${ }^{121}$ APL 55/2 Księga wizytacji parafii Lewiczyn, s. 17; Kiełbowska, Parafia Lewiczyn, s. 67.

${ }^{122}$ APL 55/2 Księga wizytacji parafii Lewiczyn, s. 17.

${ }^{123}$ Kiełbowska, Parafia Lewiczyn, s. 51.

${ }^{124}$ APL 55/2 Księga wizytacji parafii Lewiczyn, s. 35.

125 Tamże, s. 17. 
szowi pomocą przy pracy duszpasterskiej w sanktuarium. Do domu rekolekcyjnego zakupiono także 60 kompletów łóżek oraz nowe stoły i ławy dla 120 osób do jadalni ${ }^{126}$. Według akt wizytacji dziekańskiej, w jednym tylko roku z domu rekolekcyjnego korzystało około 200 osób, uczestniczących w 15-dniowych turnusach. Ponadto przyjeżdżały grupy z terenu diecezji na spotkania weekendowe. W kwietniu 1992 r. budynek został uszkodzony przez pożar. Spłonął dach, a zniszczeniu uległa także część pomieszczeń na piętrze ${ }^{127}$.

W dniu 16 kwietnia 1986 r. Jan Paweł II podczas audiencji udzielił specjalnego błogosławieństwa wszystkim parafianom i pielgrzymom, którzy modlić się będą przed cudownym obrazem. Tekst tego błogosławieństwa podpisany przez papieża, po oprawieniu zawisł $\mathrm{w}$ prezbiterium obok ołtarza $\mathrm{z}$ cudownym wizerunkiem Matki Bożej ${ }^{128}$. Sanktuarium w Lewiczynie może się poszczycić jeszcze jednym darem papieża Polaka - pateną do konsekracji komunikantów, którą przywieziono z Rzymu 4 sierpnia 1987 r. ${ }^{129}$

Poczas pielgrzymki do Wiecznego Miasta w 1991 r. parafianie z Lewiczyna uczestniczyli w audiencji, na której przekazali papieżowi kopię cudownego obrazu Matki Bożej ${ }^{130}$.

W tym czasie utrzymano w sanktuarium zwyczaj pielgrzymek parafian przed odpustem Wniebowzięcia NMP. Kontynuowano także pracę duszpasterską $\mathrm{z}$ młodzieżą $\mathrm{w}$ ramach ruchu oazowego oraz spotkania formacyjne dla różnych grup wiekowych, odbywające się w domu rekolekcyjnym, prowadzone przez ks. Krysztofika oraz wikariusza. Protokół wizytacji wspomina także o istniejącym przy sanktuarium duszpasterstwie rolników indywidualnych, które miało się tu dobrze rozwijać ${ }^{131}$. Prymas Glemp w protokole powizytacyjnym napisał:

Należy nie ustawać w wysiłkach, aby Lewiczyn, który posiada cudowny obraz

Matki Bożej, stał się miejscem pielgrzymkowym ${ }^{132}$.

Myśl tę podjęto szczególnie w roku maryjnym 1987. Przez cały rok pielgrzymi mogli uczestniczyć w wielu uroczystościach, na które byli zapraszani biskupi. Bardzo uroczyście obchodzono odpusty oraz rozwinięto cykl nabożeństw, które towarzyszyły dniom świątecznym ${ }^{133}$. Kustosz pragnął, aby sanktuarium promieniowało na całą okolicę także bogactwem życia kulturalnego, zorganizował więc W świątyni wstawę malarstwa oraz koncert recytatorski ${ }^{134}$. Na początku maja 1990 roku reżyser Janusz Zaorski kręcił w Lewiczynie związane z kultem maryjnym sceny, które później znalazły się w jednym z odcinków filmu „Panny i Wdowy”135.

\footnotetext{
${ }^{126}$ Tamże, s. 29.

${ }^{127}$ APL 55/2 Księga wizytacji parafii Lewiczyn, s. 45.

${ }^{128}$ APL 42/2 Kronika parafialna 1980-2012, s. 83; Kiełbowska, Parafia Lewiczyn, s. 139.

${ }^{129}$ Kiełbowska, Parafia Lewiczyn, s. 139.

${ }^{130}$ Tamże, s. 139.

${ }^{131}$ APL 55/2 Księga wizytacji parafii Lewiczyn, s. 30-33.

132 Tamże, s. 27.

${ }^{133}$ APL, Rok maryjny w Sanktuarium Matki Bożej w Lewiczynie Pani Ziemi Grójeckiej, s. 1-4.

${ }^{134}$ APL 42/2 Kronika parafialna 1980-2012, s. 85.

${ }^{135}$ Matyjas, Z dziejów Grójecczyzny, s. 86; Kiełbowska, Parafia Lewiczyn, s. 32.
} 
Z dniem 9 sierpnia 1992 roku ks. Grzegorz Krysztofik został mianowany proboszczem parafii w Raszynie, a jego następcą został ks. Czesław Aulich ${ }^{136}$. Nowy proboszcz przejął prace remontowe w świątyni, jak również zadanie uporządkowania jej otoczenia. W związku z pracami remontowymi w domu parafialnym zorganizowano zbiórkę pieniędzy, loterie fantowe w dni odpustów: 15 sierpnia i 8 września, co pozwoliło wykonać prace blacharskie na domu parafialnym w lutym 1993 r., a w marcu wykonano prace wewnątrz budynku. W dniu 11 maja, podczas odpustu Matki Kościoła, wyremontowane pomieszczenia w domu parafialnym poświęcił bp W. Miziołek ${ }^{137}$. W październiku wykonano ostatnie prace remontowe pomieszczeń na piętrze domu parafialnego Jana Pawła II, wzmocniono deski i położono modrzewiową boazerię $e^{138}$.

Przed odpustem 15 sierpnia dzięki składkom parafian udało się odnowić ołtarz główny z cudownym obrazem, a także zabytkową ambonę z XVIII wieku - dar Bazylego Walickiego. Zarówno odnowiony ołtarz, jak i ambonę poświęcił w czasie uroczystości Narodzenia NMP bp Marian Duś'139.

W listopadzie odnowiono boczny ołtarz z figurą Chrystusa Ukrzyżowanego. Oczyszczono i pozłocono znajdujące się w tym ołtarzu tabernakulum. Odnowiony ołtarz został poświęcony w odpust Niepokalanego Poczęcia NMP ${ }^{140}$. W czerwcu 1994 r. konserwacji poddano zabytkowe stacje drogi krzyżowej znajdujące się w kościele, a na początku września oddano do renowacji dwie zabytkowe ramy obrazów $^{141}$. Do końca 1994 r. odnowiono ramy wszystkich zabytkowych obrazów znajdujących się w świątyni. W 1996 r. ks. Aulich wraz z parafianami ufundował do kościoła wotum w postaci obrazu, przedstawiającego św. Wojciecha, jednego $\mathrm{z}$ patronów tutejszej parafii ${ }^{142}$.

Z myślą o pielgrzymach, na południe od kościoła, niedaleko bramy wejściowej, zbudowano parking oraz nową drogę prowadzącą do świątyni. Wiosną 1994 r. zasadzono przy parkingu ozdobne krzewy ${ }^{143}$. Od maja do czerwca 1996 r. ułożony został chodnik z kostki brukowej wokół świątyni ${ }^{144}$.

We wrześniu 1994 r. podczas odpustu w Lewiczynie obchodzono dekanalne Święto Rodzin. Na uroczystości przybyły pielgrzymki ze wszystkich parafii dekanatu grójeckiego ze swymi duszpasterzami, a także pielgrzymi z dekanatu mogielnickiego. Mszę św. odprawił bp Marian Duś, odczytano słowo prymasa

${ }^{136}$ Ks. Czesław Aulich urodził się w Kutnie 1 września 1943 r. Święcenia kapłańskie przyjął 6 czerwca 1971 r. Pracował jako wikariusz w Chodakowie, Piastowie i Warszawie, był proboszczem w Szymanowie, a od czerwca 1992 r. w Lewiczynie, APL 55/2 Księga wizytacji parafii Lewiczyn, s. 37.

${ }^{137}$ APL 42/2 Kronika parafialna 1980-2012, s. 90; APL 55/2 Księga wizytacji parafii Lewiczyn, s. 43-45.

${ }^{138}$ APL 42/2 Kronika parafialna 1980-2012, s. 92.

${ }^{139}$ Tamże, s. 91.

${ }^{140}$ APL 42/2 Kronika parafialna 1980-2012, s. 92.

${ }^{141}$ Tamże, s. 93-94.

142 Tamże, s. 101.

143 Tamże, s. 95-96.

${ }^{144}$ Tamże, s. 101. 
J. Glempa, który nie mógł przybyć na uroczystości z racji wyjazdu do Rzymu. W tym dniu swoje przyrzeczenia odnowili małżonkowie, obchodzący rocznicę ślubu. Otrzymali oni na pamiątkę obrazki z wizerunkiem Matki Bożej Lewiczyńskiej i błogosławieństwem prymasa ${ }^{145}$.

Wyjątkowym dla Lewiczyna był rok 1995 - dwudziesta rocznica koronacji cudownego obrazu Matki Bożej. W lutym, z okazji święta NMP z Lourdes, odbyła się dekanalna pielgrzymka chorych do lewiczyńskiego sanktuarium. W marcu zorganizowane zostało spotkanie modlitewne wójtów i sołtysów z dekanatów grójeckiego, tarczyńskiego, piaseczyńskiego, konstancińskiego, czerskiego, mogielnickiego oraz wareckiego. W spotkaniu tym wziął udział bp Piotr Jarecki oraz dziekan grójecki ks. Stanisław Laskowski ${ }^{146}$.

W dniach 25-31 marca wierni rozpoczęli duchowe przygotowania do obchodów dwudziestolecia koronacji cudownego obrazu w ramach misji parafialnych ${ }^{147}$. Przed przypadającymi na czerwiec uroczystościami rocznicowymi uprzątnięto teren wokół kościoła, przeprowadzono prace przy ołtarzu polowym. Wykonano również zaproszenia na uroczystości, które rozwieszono w parafiach dekanatu grójeckiego i sąsiednich dekanatów.

Dnia 5 czerwca Lewiczyn uroczyście obchodził dwudziestą rocznicę koronacji cudownego obrazu Matki Bożej. Uroczystą sumę celebrował kard. Józef Glemp, prymas Polski, wraz z bp Kazimierzem Romaniukiem, ordynariuszem warszawsko-praskim i Józefem Zawitkowskim, biskupem pomocniczym diecezji łowickiej. Przybyło też pięciu innych biskupów, wielu kapłanów z dekanatu grójeckiego i innych dekanatów archidiecezji warszawskiej, diecezji warszawsko-praskiej oraz diecezji łowickiej. Według relacji księdza kustosza uroczystość zgromadziła kilka tysięcy ludzi ${ }^{148}$. Kard. Glemp wygłosił kazanie na temat królewskiej roli Matki Bożej, wspomniał o dziejach sanktuarium w Lewiczynie, złączonych z historią ziemi grójeckiej i południowego Mazowsza. Prymas w homilii zapytał wiernych:

My łatwo nazywamy Maryję królową Polski, ale czy jej królowanie odpowiada postawie naszych serc? $?^{149}$.

Ks. Aulich przestał pełnić funkcję kustosza lewiczyńskiego sanktuarium oraz proboszcza parafii na początku lutego 1997 r., obejmując parafię św. Anny w Piasecznie ${ }^{150}$.

Od 6 lutego 1997 r. pracę w sanktuarium lewiczyńskim podjął ks. Paweł Piotrowski. Rozpoczął on szereg prac związanych z remontem zabytkowej świątyni. W kościele postanowiono zainstalować ogrzewanie, a ponieważ jest to budowla

${ }_{145}$ Tamże, s. 94-95; Kiełbowska, Parafia Lewiczyn, s. 33.

${ }^{146}$ APL 42/2 Kronika parafialna 1980-2012, s. 97.

147 Tamże, s. 97.

148 Tamże, s. 99.

${ }^{149}$ P. B., Dwudziesta rocznica koronacji Matki Bozej w Lewiczynie, „Wiadomości Archidiecezjalne Warszawskie", 6 (1995) s. 752.

${ }^{150}$ APL 42/2 Kronika parafialna 1980-2012, s. 103; Ks. Piotrowski urodził się 15 października 1955 r. w Piasecznie, święcenia kapłańskie przyjął 1 czerwca 1980 r. w Warszawie. Przed przybyciem do Lewiczyna pełnił posługę wikariusza w parafii Opatrzności Bożej w Warszawie. 
drewniana, należało wybrać odpowiednią instalację, która spełniałaby swoje zadanie, a jednocześnie była bezpieczna dla obiektu i mogła być zaakceptowana przez Wojewódzkiego Konserwatora Zabytków. Ostatecznie zdecydowano się wybrać system napromienników halogenowo-kwarcowych, emitujących promienie podobne do promieni słonecznych. Po uzyskaniu zgody konserwatora został on zainstalowany w kościele pod koniec grudnia 1997 roku $^{151}$. Dbając o bezpieczeństwo świątyni, założono także w kościele nowy system alarmowy. W maju tego samego roku odnowiono konstrukcję metalową nad ołtarzem polowym oraz pomalowano maszty na skarpie kościelnej. W samym kościele dokonano prac remontowych podłogi w miejscach dawnych ołtarzy bocznych ${ }^{152}$.

Po Bożym Ciele 1998 r. rozpoczęto remont, wadliwie położonego przed laty dachu, który przeciekał, a woda zalewała świątynię po większych opadach deszczu. Z powodu kosztów, ograniczono się tylko do uszczelnienia dachu silikonem dekarskim. W sierpniu tegoż roku dokonano również impregnacji drewna na całym kościele ${ }^{153}$.

Dzień 5 października tego samego roku był jednym z najbardziej dramatycznych momentów w dziejach sanktuarium. W trakcie nabożeństwa różańcowego w zakrystii kościoła wybuchł pożar. Zaczęła płonąć szafa, w której ministranci przechowują alby. Dym zauważyła obecna na nabożeństwie katechetka. Dzięki szybkiej reakcji proboszcza, który wbiegł do zadymionej zakrystii i ugasił ogień, zabytkowa świątynia nie spłonęła. Na miejsce zdarzenia przybył zastęp miejscowej straży pożarnej, a ks. Piotrowskiego, który przebywał w zadymionej zakrystii odwieziono do szpitala w Grójcu. Według ekspertyzy specjalistów była to próba podpalenia. W związku z tym przez kilka tygodni, co noc straż przy świątyni pełnili mężczyźni z każdej miejscowości należącej do parafii ${ }^{154}$. W 1999 r. w celu zwiększenia bezpieczeństwa kościoła założono bramy w ogrodzeniu oraz sześć czujników elektronicznych. W świątyni zainstalowano również system antywłamaniowy ${ }^{155}$. Wykonano także nowy, metalowy dach na szkielecie zadaszenia ołtarza polowego ${ }^{156}$. W 2000 r., wybudowano nowy ołtarz polowy oraz ambonkę, zainstalowano kolejne bramy wokół muru kościelnego. Przy plebanii zbudowano nowy parking, wyłożony kostką brukową ${ }^{157}$.

Z okazji Roku Świętego 2000, decyzją metropolity warszawskiego, lewiczyńska świątynia stała się najważniejszym sanktuarium w południowej części archidiecezji, gdzie można było codziennie uzyskać odpust jubileuszowy ${ }^{158}$. Forma uczczenia roku jubileuszowego było nawiedzenie wszystkich rodzin w parafii przez kopię obrazu Jezusa Miłosiernego ${ }^{159}$. Z okazji rocznicy koronacji

${ }^{151}$ Tamże, s. 114; APL 55/2 Księga wizytacji parafii Lewiczyn, s. 63.

${ }^{152}$ APL 42/2 Kronika parafialna 1980-2012, s. 117.

${ }^{153}$ Tamże, s. 119.

${ }^{154}$ APL 42/2 Kronika parafialna 1980-2012, s. 124-126.

155 Tamże, s. 129.

156 Tamże.

157 Tamże, s. 132.

158 Tamże, s. 130; H. Małecki, A. Dziurok, Sanktuaria odpustu jubileuszowego w archidiecezji warszawskiej, Warszawa 2000, s. 44-47.

${ }^{159}$ APL 42/2 Kronika parafialna 1980-2012, s. 127-128. 
odnowiono srebrne okłady, nazywane tradycyjnie sukienkami, wraz z koronami znajdującymi się na wizerunku Matki Bożej. Pracami renowacyjnymi zajęli się złotnik Włodzimierz Kowalski oraz jego syn, artysta rzeźbiarz Dariusz Kowalski z Warszawy. W trakcie prac konserwatorskich oczyszczono sukienki i korony, renowacji poddano kamienie szlachetne z koron papieskich. Wykonano specjalny podkład pod tło, na którym znajdują się okłady oraz pozłocono gwiazdy znajdujące się na tle wizerunku ${ }^{160}$. Odnowione sukienki i korony zostały poświęcone 12 czerwca 2000 roku przez bpa Piotra Jareckiego w dniu odpustu w uroczystość Matki Kościoła ${ }^{161}$.

W Roku Jubileuszowym przybyły do sanktuarium Matki Bożej liczne pielgrzymki. Wyjątkowy charakter miało spotkanie dzieci, które w 2000 r. przystąpiły po raz pierwszy do Komunii Świętej. Przybyły one do Lewiczyna z parafii dekanatu grójeckiego oraz sąsiednich dekanatów w dniu 17 czerwca. Po uroczystej mszy św. przy ołtarzu polowym, celebrowanej przez bp Tadeusza Pikusa, w świątyni odbył się konkurs piosenki religijnej.

Główne uroczystości związane z rocznicą koronacji obrazu Pani Ziemi Grójeckiej odbyły się w dniach 13-15 sierpnia. Rozpoczął je uroczystą sumę dziękczynną za koronację obrazu prymas J. Glemp. Koncelebransami byli poprzedni opiekunowie sanktuarium, w tym ks. J. Makowski, który przygotowywał uroczystości koronacyjne. Pamiątką jubileuszu były trzy tablice z brązu, wykonane przez rzeźbiarza Dariusza Kowalskiego. Przedstawiają one moment koronacji obrazu Matki Bożej przez kard. S. Wyszyńskiego i kard. K. Wojtyłę, z podpisem „XXV-lecie koronacji obrazu Matki Bożej Lewiczyńskiej”. W dniu 15 sierpnia przybyli pielgrzymi z całego regionu, aby dziękować za koronację wizerunku Matki Bożej ${ }^{162}$.

Lata 2001-2003 to czas przygotowania do jubileuszu 400-lecia obecności obrazu Matki Bożej w Lewiczynie, przeplatany uroczystościami odpustowymi oraz rytmem roku liturgicznego. W 2001 r. rozpoczęto prace przy uzupełnianiu ubytków tynku kościoła, zainstalowano też nowy system nagłośnienia w świątyni oraz przy ołtarzu polowym. W 2002 roku zainstalowano nowy system antywłamaniowy oraz przeciwpożarowy. Zakupiono cztery ornaty z emblematami maryjnymi. Sporządzono również projekt medalików z wizerunkiem Matki Bożej Lewiczyńskiej ${ }^{163}$.

Rok 2003 był obchodzony jako Rok Różańca, w związku z tym w sanktuarium szczególną uwagę zwrócono wówczas na nabożeństwa październikowe. Tajemnice różańca rozważano także przez cały rok w trakcie nabożeństw do Matki Bożej. Odnowiono również zabytkowy różaniec drewniany, noszony dawniej przez młodzież w procesjach. Po renowacji, różańcem tym otoczono cały ołtarz z Najświętszym Sakramentem ${ }^{164}$.

${ }^{160}$ Tamże, s. 130; APL, Opis prac konserwatorskich przy sukience Matki Bożej Lewiczyńskiej, s. 3.

${ }^{161}$ APL 42/2 Kronika parafialna 1980-2012, s. 130.

162 Tamże, s. 131-132.

${ }^{163}$ APL 42/2 Kronika parafialna 1980-2012, s. 134-135.

164 Tamże, s. 136. 
W uroczystość Bożej Rodzicielki rozpoczęły się obchody jubileuszu 400-lecia obecności w lewiczyńskiej świątyni cudownego obrazu Matki Bożej. Przygotowanie do głównych uroczystości miało wymiar duchowy i materialny. Cały okres roku liturgicznego był pełen odniesień do jubileuszu. Duchowym przygotowaniem były misje parafialne, które odbyły się w Lewiczynie w dniach 27-31 maja ${ }^{165}$. Materialnym darem było odnowienie cudownego obrazu (grudzień 2003 - marzec 2004 r.), przeprowadzone przez prof. Mariana Paciorka z Krakowa. Zaimpregnowano wówczas deskę, na którą naklejony jest obraz i uzupełniono ubytki w warstwie malarskiej metodą punktowego scalania ${ }^{166}$.

Główne uroczystości jubileuszowe odbyły się 31 maja, na zakończenie misji parafialnych. Był to jednocześnie odpust związany z uroczystością Matki Kościoła. W tym dniu przybył do Lewiczyna po raz kolejny prymas J. Glemp, który odprawił uroczystą sumę przy ołtarzu polowym. Koncelebrowali ją dawni kustosze sanktuarium, księża: Jan Makowski, Stanisław Dusiło, Grzegorz Krysztofik, Czesław Aulich oraz pochodzący z Anielina parafianin, ks. Paweł Kudlak. Prymas poświęcił krzyż misyjny oraz obraz przedstawiający uroczystość koronacji w 1975 roku, autorstwa Teresy i Dariusza Kowalskich z Warszawy. Wspomniany obraz został umieszczony w prezbiterium. Pielgrzymi mogli obejrzeć przedstawienie o dziejach sanktuarium i miejscowości pt. Czterysta lat cudownego obrazu, przygotowane przez nauczycieli i dzieci ze szkół podstawowych z Lewiczyna i Zaborowa. Na uroczystość, obok duchowieństwa, przybyli także przedstawiciele władz gminy. Po zakończeniu uroczystości, zaproszonych gości podjęto obiadem w remizie strażackiej. Zostali oni obdarowani pamiątkami z okazji jubileuszu sanktuarium: krzyżykiem wykonanym z dawnej ramy cudownego obrazu oraz tekstem kazania prymasa S. Wyszyńskiego, wygłoszonego w dniu koronacji obrazu Matki Bożej 10 sierpnia 1975 roku $^{167}$.

W czerwcu 2004 r. ks. Paweł Piotrowski zakończył posługę w sanktuarium lewiczyńskim, podejmując funkcję proboszcza parafii Dzieciątka Jezus w Warszawie.

Od 4 lipca 2004 roku proboszczem w Lewiczynie został ks. Zdzisław Karaś. Kanonicznego wprowadzenia na urząd proboszcza parafii i kustosza sanktuarium maryjnego dokonał dziekan grójecki ks. Stanisław Laskowski ${ }^{168}$.

Ze względu na zwiększający się ruch pielgrzymkowy, proboszcz poprosił o pomoc księży z Ośrodka Misyjnego. Od 7 listopada w każdą niedzielę do pomocy duszpasterskiej przybywali księża przygotowujący się do wyjazdu na misje. Konieczne okazało się także dokończenie remontu Domu Pielgrzyma. Założono instalację elektryczną, otynkowano budynek, na poddaszu wykonano dwa dodatkowe pokoje i łazienkę. Na placu przed Domem Pielgrzyma ułożono kostkę bru-

${ }^{165}$ APL 42/2 Kronika parafialna 1980-2012, s. 137.

166 Tamże, s. 137; APL, Opis prac konserwatorskich przy obrazie Matki Bożej Lewiczyńskiej, s. 1-12.

${ }^{167}$ APL 42/2 Kronika parafialna 1980-2012, s. 139.

${ }^{168}$ Tamże, s. 140-141. Ks. Zdzisław Karaś przed podjęciem obowiązków kustosza i proboszcza w Lewiczynie zarządzał gospodarstwem rolnym WMSD w Czubinie; por. G. Kalwarczyk, Duchowieństwo Archidiecezji Warszawskiej w 2008 roku, Warszawa 2009, s. 166. 
kową. Budynek został oddany do użytku w zimie 2004 r. ${ }^{169}$ Poświęcenia odnowionego Domu Pielgrzyma dokonał prymas J. Glemp w uroczystość Matki Kościoła, 5 czerwca 2006 r. ${ }^{170}$

Zmianie uległ także wygląd samej świątyni - do ołtarza głównego powróciło tabernakulum, oraz zmodernizowano jego podium. Prace te zostały wykonane zgodnie z zleceniami ostatniej wizytacji kanonicznej z 2003 r. ${ }^{171}$ Ponadto zainstalowano specjalny system zabezpieczający cudowny obraz przed kradzieżą bądź zniszczeniem. System ten składa się ze specjalnej kasety, w której znajduje się wizerunek, oraz zasłony. Idąc za przykładem innych sanktuariów, nagrano intradę, która jest odtwarzana w czasie odsłaniania i zasłaniania obrazu ${ }^{172}$. Przy cudownym obrazie oraz na ścianach prezbiterium zawisły gabloty, w których umieszczono wota składane Matce Bożej. Na ołtarzu głównym powieszono dwie gabloty z biżuterią z bursztynu oraz srebrnymi i złotymi sercami wotywnymi. W czterech gablotach na ścianach prezbiterium znalazły się: różnego rodzaju biżuteria, sznury korali oraz krzyżyki, różańce i proporczyki. Na południowej ścianie świątyni, obok ambony, pojawiły się też reprodukcje sześciu zabytkowych obrazków wotywnych z XVII i XVIII wieku, przestawiające sceny cudów dokonanych za wstawiennictwem Matki Bożej Lewiczyńskiej ${ }^{173}$.

Odpust z okazji uroczystości Wniebowzięcia NMP był połączony z obchodami trzydziestej rocznicy koronacji cudownego obrazu. Uroczystą sumę odprawił bp Tadeusz Pikus, a wieczorem w sanktuarium wierni zgromadzili się na modlitwie różańcowej, po której odśpiewano Apel Maryjny ${ }^{174}$.

W październiku przybyli do Lewiczyna z pielgrzymką alumni i profesorowie Wyższego Metropolitalnego Seminarium Duchownego w Warszawie, a w listopadzie ks. Z. Karaś zorganizował spotkanie z okazji Dnia Seniora. Po mszy świętej w sanktuarium, zaproszeni goście zostali podjęci poczęstunkiem w Sali Jana Pawła II ${ }^{175}$.

W 2006 r., idąc z duchem czasu, kustosz postanowił stworzyć stronę internetową sanktuarium i parafii, aby pomóc zainteresowanym osobom w dostępie do informacji o dziejach miejsca kultu oraz odbywających się w Lewiczynie uroczystościach $^{176}$.

W kwietniu tego roku, w dniu 1. rocznicy śmierci Jana Pawła II, po mszach św. o 9 i 11:30 w sali jego imienia zorganizowano pokaz filmu Karol, człowiek,

${ }^{169}$ APL 42/2 Kronika parafialna 1980-2012, s. 142-144; APL 55/2 Księga wizytacji parafii Lewiczyn, Kwestionariusz duszpastersko-katechetyczny przed wizytacją kanoniczną, s. 8.

${ }^{170}$ APL 42/2 Kronika parafialna 1980-2012, s. 148.

${ }^{171}$ APL 55/2 Księga wizytacji parafii Lewiczyn, Protokół wizytacji kanonicznej parafii pw. Świętego Wojciecha i Świętego Marcina w Lewiczynie, przeprowadzonej w dniach 7-8 września 2003 przez Biskupa Pomocniczego Archidiecezji Warszawskiej, Piotra Jareckiego, s. 3-4.

${ }^{172}$ APL 55/2 Księga Wizytacji parafii Lewiczyn, Kwestionariusz duszpastersko-katechetyczny przed wizytacją kanoniczną, s. 11.

${ }^{173}$ Tamże, s. 145.

174 Tamże.

175 Tamże, s. 146.

${ }^{176}$ Tamże, s. 147. 
który zostat papieżem, wieczorem zaś w świątyni obył się wieczór poezji deklamowanej przez młodzież miejscowej parafii ${ }^{177}$.

W grudniu odbyła się w sanktuarium maryjnym konferencja rejonowa duchowieństwa archidiecezji warszawskiej, połączona z tradycyjnie odbywającym się w Lewiczynie nabożeństwem pokutnym dla duchowieństwa. Pod przewodnictwem bp M. Dusia modliło się wówczas około 120 księży z siedmiu dekanatów.

W celu rozwoju kultu maryjnego w sanktuarium wprowadzono nowe nabożeństwa, niepraktykowane wcześniej w Lewiczynie oraz zmodyfikowano istniejące, aby zaktywizować wiernych ${ }^{178}$.

W listopadzie 2007 r. postanowiono wznieść przy kościele pomnik Jana Pawła II, dla oddania czci wielkiemu rodakowi oraz podkreślenia pamięci o jego udziale w koronacji cudownego obrazu. Pomnik autorstwa Dominika Wdowskiego i Katarzyny Kusak, ma 2,5 metra wysokości, został odlana z brązu w warsztacie Jacka Guzawy. Ustawiono go na placu przed ołtarzem polowym. Pomnik poświecił abp Kazimierz Nycz 13 października 2008 r. ${ }^{179}$

Od czerwca 2008 r. wierni przybywający do sanktuarium mogą modlić się przed relikwiami św. brata Alberta Chmielowskiego, które przekazały siostry albertynki. Relikwiarz umieszczono w bocznym ołtarzu wraz z certyfikatem potwierdzającym autentyczność relikwii ${ }^{180}$.

W maju 2009 roku przy sanktuarium rozpoczęto wznoszenie kapliczek z tajemnicami różańcowymi w miejscu dawnego sadu parafialnego. Zaplanowano wzniesienie 20 kapliczek murowanych. Natomiast z myślą o pielgrzymach, zbudowano wiatę oraz boisko sportowe ${ }^{181}$.

W uroczystość odpustową, 15 sierpnia bp Tadeusz Pikus poświęcił znajdującą się w pobliżu kościoła ścianę o konturach Polski zwieńczoną krzyżem, w której wnękach znalazła się ziemia z miejsc o szczególnym znaczeniu dla narodu polskiego i jego najnowszej historii. Znalazła się tam także ziemia z cmentarza w Katyniu oraz Monte Cassino. Z obu stron monumentu posadzono „drzewa katyńskie"182.

Proboszczowi udało się po licznych zabiegach, doprowadzić do przeniesienia dożynek powiatowych do Lewiczyna, co znacznie podniosło rangę parafii i miejscowości. Po mszy św., którą odprawił abp K. Nycz, wystąpił zespół pieśni i tańca „Warszawianka”. Gościem honorowym był aktor Wojciech Siemion. Przybyli na uroczystości mogli obejrzeć stoiska gminy oraz firm z terenu powiatu ${ }^{183}$.

Ks. Karaś podobnie jak poprzednicy starał się o zachowanie dla potomnych skarbów przeszłości zgromadzonych w świątyni oraz jej otoczeniu. Renowacji poddano m.in. zabytkowy zegar słoneczny oraz groby na cmentarzu przykościelnym $^{184}$.

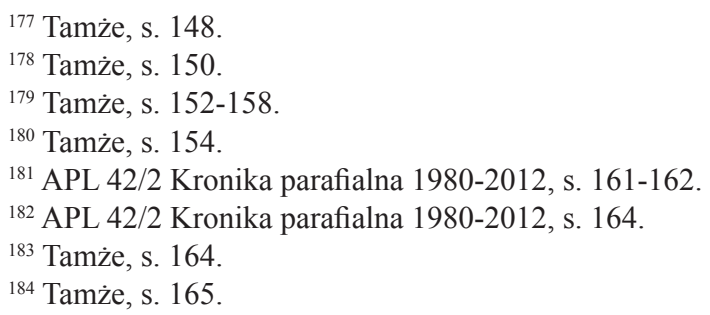


W kwietniu 2010 r.,w związku z przygotowaniami do beatyfikacji Jana Pawła II, sprowadzono do Lewiczyna krzyż, który papież trzymał w czasie Drogi Krzyżowej w $2005 \mathrm{r}$. Na modlitwę przybyli wierni z parafii dekanatu grójeckiego wraz ze swoimi duszpasterzami. W tym dniu odprawiono dwie msze św. oraz Drogę Krzyżową. Czuwanie modlitewne prowadziły różne grupy wiernych: uczniowie gimnazjum z Belska Dużego, uczniowie ze szkoły podstawowej z Belska Dużego, której patronem jest Jan Paweł II, koła Żywego Różańca oraz członkowie Akcji Katolickiej. Każdy z przybyłych pielgrzymów otrzymał też pamiątkowy obrazek przedstawiający krzyż papieski oraz panoramę sanktuarium ${ }^{185}$.

Wieczorem 1 maja wierni zgromadzili się w sanktuarium na modlitwie różańcowej, by dziękować za dar wyniesienia do chwały ołtarzy papieża-Polaka. Pierwszy raz oddano też cześć relikwiom błogosławionego, przekazanym do lewiczyńskiej świątyni. Relikwiarz zawiera fragment papieskiej sutanny. Dla podkreślenia pamięci o udziale Jana Pawła II w uroczystościach koronacyjnych w 1975 r. w świątyni powieszono gablotę z ornatem, w którym przyszyły papież celebrował wówczas mszę św. ${ }^{186}$

W maju 2010 ks. Kard. Kazimierz Nycz poświęcił kolejne stacje różańcowe - tajemnice światła oraz kaplicę z figurą Matki Bożej z Lourdes, która znajduje się na zwieńczeniu placu różańcowego na północ od kościoła ${ }^{187}$, a dzieci przystępujące do Pierwszej Komunii Świętej złożyły Matce Bożej wotum dziękczynne, pozłacaną różę z bursztynem, którą umieszczono obok cudownego obrazu w ołtarzu głównym ${ }^{188}$.

W 2012 r. ks. Z. Karaś zorganizował w Lewiczynie spotkanie formacyjne dla delegatów kół Żywego Różańca z dekanatów: czerskiego, mogielnickiego, grójeckiego, konstancińskiego, piaseczyńskiego, tarczyńskiego oraz wareckiego. Spotkanie odbyło się 3 czerwca, a poprowadził je o. Stanisław Przepierski, dominikanin, asystent Żywego Różańca w archidiecezji warszawskiej ${ }^{189}$.

Z myślą o coraz liczniej odwiedzających sanktuarium w miesiącach letnich pielgrzymach, postanowiono, że w niedziele od maja do października kościół będzie otwarty od godziny 13 do 17 . Dyżury w świątyni w tym czasie pełnili członkowie Akcji Katolickiej ${ }^{190}$.

W czasie pełnienia funkcji proboszcza przez ks. Karasia, po przerwie, w sanktuarium posługę duszpasterską zaczęli pełnić wikariusze: Jan Kuźniar, Marcin Kościecha, Krzysztof Kołakowski, Robert Walantyk. Ks. Z. Karaś zakończył posługę duszpasterską w Lewiczynie w lipcu 2012 r., a jego miejsce zajął dotychczasowy wikariusz parafii św. Mikołaja w Grójcu ks. Andrzej Juńczyk.

\footnotetext{
185 Tamże, s. 167.

${ }^{186}$ APL 42/2 Kronika parafialna 1980-2012, s. 168.

187 Tamże, s. 169-170.

188 Tamże, s. 170.

189 Tamże, s. 174-175.

${ }^{190}$ Tamże, s. 176.
} 


\section{Władze lokalne wobec sanktuarium w okresie PRL i III Rzeczpospolitej}

W protokołach wizytacyjnych parafii z okresu Polski Ludowej, często spotkać można skargi ówczesnych proboszczów na utrudnienia w pracach przy odnawianiu kościoła w Lewiczynie, ze strony władz gminnych lub powiatowych ${ }^{191}$. Z dużymi przeszkodami w prowadzeniu prac przy kościele spotykał się ks. Jan Makowski. Mimo przychylności, jaką wobec planów remontu zabytkowej świątyni okazywał Wojewódzki Konserwator Zabytków, władze powiatowe w Grójcu nie ułatwiały pracy proboszczowi. Ks. Makowski, na podstawie nakazu konserwatora z 1963 r., skupował drewno, potrzebne do remontu. Udało się mu wykonać niezbędne, zalecane przez konserwatora prace przy dzwonnicy oraz na jednej ze ścian kościoła ${ }^{192}$. Kolejne nie mogły być podjęte ze względu na konieczność zainicjowania nowych starań o uzyskanie odpowiedniej ilości drzewa modrzewiowego z nadleśnictwa w Głuchowie. Od 1967 r. otrzymanie materiału do podjęcia dalszych prac remontowych możliwe było tylko $\mathrm{w}$ wyniku przydziału $\mathrm{z}$ urzędu powiatowego. $\mathrm{Na}$ prośbę ks. Makowskiego, władze odpowiedziały żądaniem wyliczenia, ile drzewa potrzeba do prowadzenia dalszych prac ${ }^{193}$. Ks. Makowski wysłał do władz powiatowych pismo z wyliczeniem sporządzonym przez inżyniera Tadeusza Koczaja. $\mathrm{Z}$ urzędu powiatowego nadesłano wówczas polecenie wykonania odpowiednich planów prac remontowych ${ }^{194}$. Odpowiednie plany oraz kosztorys sporządził Karol Kowalski, a wszystkie materiały zostały przez powiat odesłane do władz wojewódzkich w Warszawie ${ }^{195}$. Wojewódzka Rada Narodowa w piśmie do proboszcza wyraziła zdziwienie postępowaniem kierownictwa powiatu, który sam mógł podjąć decyzję w tej sprawie. Władze wojewódzkie wyznaczyły jednak dwóch ekspertów do opracowania planów na podstawie nadesłanych $\mathrm{z}$ urzędu powiatowego materiałów ${ }^{196}$. Po przedstawieniu planów Wojewódzka Rada Narodowa przyznała $63 \mathrm{~m}^{3}$ drzewa na dalszy remont zabytkowej świątyni ${ }^{197}$. Nie udało się jednak wykorzystać w pełni przydziału, gdyż po uzyskaniu $6 \mathrm{~m}^{3}$, decyzją przewodniczącego Powiatowej Rady Narodowej w Grójcu, Błażejewskiego, z dnia 17 sierpnia 1970 r., przydział drzewa został cofnięty. Ks. Makowski nie ustawał w staraniach, aby zmienić tę niekorzystną decyzję. Tym bardziej, że z informacji uzyskanych od pracowników nadleśnictwa w Głuchowie, wiadomym było, że wycinane modrzewie były odpowiedniej długości i rodzaju, idealnie nadając się do remontu zabytkowego kościoła w Lewiczynie ${ }^{198}$. Kustosz podjął starania o zmianę decyzji Powiatowej Rady Narodowej, tłumacząc w kolejnych pismach, potrzebę kontynuowania prac, a także wykonania zaleceń konserwatora. Nie przyniosło to jednak żadnego rezultatu. W piśmie z 17 października do Wojewódzkiej Rady Naro-

${ }^{191}$ APL 41/1, Kronika parafialna 1945-1980, s. 48-50.

${ }^{192}$ APL 18, Dokumenty dotyczące remontu kościoła parafialnego w Lewiczynie, k. 78; APL 41/1, Kronika parafialna 1945-1980, s. 48

${ }^{193}$ APL 41/1, Kronika parafialna 1945-1980, s. 48

194 Tamże, s. 49.

195 Tamże; APL 60, Decyzje i nakazy wojewódzkiego konserwatora zabytków, k. 1-2.

${ }^{196}$ APL 41/1, Kronika parafialna 1945-1980, s. 49.

197 Tamże.

${ }^{198}$ APL 41/1, Kronika parafialna 1945-1980, s. 50. 
dowej ks. Makowski skarżył się, że władze mówią o ochronie zabytków, lecz gdy słowa przychodzi zamienić w czyn, piętrzą trudności, zamiast okazywać pomoc. Powiat natomiast pozostaje głuchy na potrzeby małej parafii, która sama musi ponosić ciężar ogromnych kosztów remontu wiekowej świątyni ${ }^{199}$.

Reforma administracyjna kraju, dokonana na podstawie znowelizowanej konstytucji z 28 maja 1975 r., wprowadziła dwustopniowy podział administracyjny. Zlikwidowano powiaty, zwiększono liczbę województw z 17 do 49, a część miast powiatowych stała się wojewódzkimi ${ }^{200}$. Gmina Belsk Duży, w której leżał Lewiczyn, znalazła się w nowo utworzonym województwie radomskim.

Już w 1976 r. złożył w Lewiczynie pierwszą wizytę wojewódzki konserwator zabytków, a sprawa remontu świątyni stała się znowu aktualna. Pismem z dnia 14 czerwca konserwator polecił dostarczyć podanie o wznowienie prac remontowych, wykaz prac remontowych wykonanych w 1970 r. oraz wykaz prac koniecznych do pojęcia w pierwszej kolejności. Zlecił również wykonanie i przesłanie do Radomia ekspertyz dotyczących obecnego stanu zabytkowej świątyni ${ }^{201}$. Po kolejnej wizycie i oględzinach w dniu 2 maja 1979 r. nakazał przeprowadzenie prac przy kościele według ekspertyz i planów dotyczących stanu świątyni oraz zlecanych prac restauracyjnych.

Nowy proboszcz, który w 1977 r. przejął po ks. Makowskim troskę o zabytek, nie licząc na pomoc ze strony władz lokalnych, postanowił prowadzić prace na miarę możliwości niewielkiej parafii. Wobec małych środków postanowił zorganizować w Belsku kwestę, której celem była zbiórka funduszy, potrzebnych do prowadzenia prac remontowych, a w czasie odpustów zorganizowano także loterię. Pod koniec sierpnia 1980 r. ks. Dusiło poinformował władze gminy w Belsku Dużym o zebranej w ten sposób kwocie pieniędzy ${ }^{202}$.

Przykrymi incydentami które miały miejsce w tym czasie były trzy włamania do kościoła. W dniu 31 lipca 1978 r. złodzieje ukradli 36 sznurów korali wiszących na tablicach wokół ołtarza głównego. Opieszale prowadzone w tej sprawie śledztwo przez komendę Milicji Obywatelskiej w Belsku Dużym, zostało umorzone 7 września 1978 r. z powodu nieustalenia sprawców ${ }^{203}$. Śledztwa w sprawie kolejnych włamań do kościoła w 1984 i 1985 r. również zostały umorzone z powodu nie wykrycia sprawców. Zrabowanych zabytkowych przedmiotów nigdy nie udało się odzyskać. Łupem złodziei w czerwcu 1984 r. padł cenny XVII-wieczny krucyfiks, dwa srebrne lichtarze oraz dwie kadzielnice. W 1985 r. z kościoła ukradziono cyborium z komunikantami i melchizedek z hostią ${ }^{204}$.

Stosunek władz lokalnych do sanktuarium, uległ zmianie w 1989 r., wraz z przemianami społeczno-politycznymi w Polsce. Lewiczyńska świątynia, stała się chlubą gminy, jak również reaktywowanego w 1999 r. powiatu grójeckiego ${ }^{205}$.

\section{Tamże.}

${ }^{200}$ A.L. Sowa, Historia polityczna Polski 1944-1991, Kraków 2011, s. 390.

${ }^{201}$ Kiełbowska, Parafia Lewiczyn, s. 63-64.

${ }^{202}$ APL 18, Dokumenty dotyczące remontu kościoła parafialnego w Lewiczynie, k. 20-21; Z. Kiełbowska, Parafia Lewiczyn, s. 65-67.

${ }^{203}$ APL 60, Decyzje i nakazy wojewódzkiego konserwatora zabytków, k. 18.

${ }^{204}$ APL 55/2 Księga wizytacji parafii Lewiczyn, s. 6; Kiełbowska, Parafia Lewiczyn, s. 30.

${ }^{205}$ Roszkowski, Historia Polski 1914-2005, s. 448-449. 
Już w 1993 r. udało się odkupić od Urzędu Gminy w Belsku Dużym teren tak zwanej Górki Bolesnej, niewielkiego wzniesienia znajdującego się na południe od wzgórza kościelnego, na którym znajduje się krzyż, a w czasie procesji na Boże Ciało usytuowany jest jeden z ołtarzy stacyjnych. Gmina pokryła też częściowo koszty budowy nowego parkingu przy kościele ${ }^{206}$. Protokoły wizytacyjne potwierdzają dobre relacje panujące miedzy kustoszem sanktuarium a władzami gminnymi w Belsku Dużym ${ }^{207}$. Widocznym elementem współpracy stała się organizacja przy sanktuarium lewiczyńskim dożynek powiatowych, przy aktywnym udziale i obecności na tych uroczystościach wspomnianych władz lokalnych, zarówno gminnych, jak i powiatowych. Ich przedstawiciele brali również udział $\mathrm{w}$ uroczystościach odpustowych ${ }^{208}$.

Wojewódzki konserwator zabytków wspierał proboszczów w kolejnych pracach remontowych przy sanktuarium oraz renowacji zgromadzonych w nim dzieł sztuki. Najważniejszą po upadku komunizmu inwestycją i zadaniem podjętym przez wspólnotę parafialną, była renowacja cudownego obrazu Matki Bożej. Ze stosownym wnioskiem wystąpił w październiku 2003 r. ks. Paweł Piotrowskii ${ }^{209}$. Wojewódzki konserwator zabytków z delegatury w Radomiu Marek Figiel wyraził zgodę na przeprowadzenie prac objętych planem restauracyjnym ${ }^{210}$. Inne prace podejmowane przez kolejnego kustosza, np. wykonanie zabezpieczenia obrazu lub renowacja zabytkowych przedmiotów z otoczenia kościoła w 2009 r., również zyskały przychylność, zainteresowanie i pomoc w uzyskaniu niezbędnych środków Wojewódzkiego Urzędu Ochrony Zabytków ${ }^{211}$.

\section{Współczesne formy i przejawy kultu w sanktuarium lewiczyńskim}

\section{a) Odpusty}

W myśl definicji słownikowej termin „odpust” określa zarówno przywilej darowania kary za grzechy odpuszczone już, co do winy, w spowiedzi, jak i sam akt uzyskania odpustu podczas uroczystości patronalnych kościoła, kaplicy, ołtarza ${ }^{212}$.

W sanktuarium lewiczyńskim dniami odpustowymi są: uroczystość Zwiastowania Pańskiego przypadająca na dzień 25 marca, poniedziałek po uroczystości Zesłania Ducha Świętego, czyli święto Maryi Matki Kościoła, uroczystość Wniebowzięcia NMP w dniu 15 sierpnia oraz święto Narodzenia NMP obchodzone 8 września. Ostatnim odpustem w Lewiczynie jest uroczystość Niepokalanego

\footnotetext{
${ }^{206}$ APL 42/2 Kronika parafialna 1980-2012, s. 92.

${ }^{207}$ APL 55/2 Księga wizytacji parafii Lewiczyn, s. 42-48.

${ }^{208}$ APL 42/2 Kronika parafialna 1980-2012, s. 156.

${ }^{209}$ APL, Prośba o zgodę na wykonanie prac konserwatorskich przy obrazie Matki Bożej Lewiczyńskiej, k. 1.

${ }^{210}$ APL, Decyzja nr. 609/2003 Zgoda na przeprowadzenie prac konserwatorskich przy obrazie Matki Boskiej Lewiczyńskiej z ołtarza głównego kościoła parafialnego w Lewiczynie, k. 1.

${ }^{211}$ APL 42/2 Kronika parafialna 1980-2012, s. 161-165.

212 J. Krukowski, Odpust, w: EK, t. 14, Lublin 2010, kol. 342-344; P. Rytel-Andrianiuk, Sanktuarium i parafia Trójcy Przenajświętszej i Świętej Anny w Prostyni, wyd. 2, Drohiczyn-Rzym-Oksford 2011, s. 112.
} 
Poczęcia NMP w dniu 8 grudnia ${ }^{213}$. Ponadto dniami odpustowymi są wspomnienia patronów parafii: św. Wojciecha - 23 kwietnia i św. Marcina - 11 listopada.

Szczególnie uroczysty charakter ma święto Wniebowzięcia NMP, które w Kościele katolickim jest jednym z głównych świąt roku liturgicznego. W sanktuarium lewiczyńskim zbierają się na nim licznie pielgrzymi z różnych stron dekanatu grójeckiego oraz dekanatów ościennych, jak również innych parafii z terenu archidiecezji warszawskiej oraz spoza jej granic. Wierni już od godzin porannych przybywają do kościoła, by uczestniczyć w celebrze. Jest to uroczystość, która od dziesięcioleci gromadziła największą liczbę wiernych. To skłoniło ks. J. Makowskiego w 1970 r. do budowy ołtarza polowego, ponieważ wierni nie mieścili się w kościele i wielu z nich z konieczności stało przed drzwiami kościoła oraz wokół świątyni na cmentarzu ${ }^{214}$. Ołtarz ten usytuowano w pobliżu świątyni przy obszernym placu, na którym od tej pory mogły gromadzić się i uczestniczyć w liturgii przybywające do sanktuarium rzesze pątników. Najważniejszą mszą w dniu 15 sierpnia jest uroczysta suma odpustowa, odprawiana, co roku o godzinie 12:00, $\mathrm{w}$ intencji parafian oraz pielgrzymów ${ }^{215}$. Po Eucharystii ulicami Lewiczyna rusza procesja eucharystyczna od ołtarza polowego drogą koło tzw. Górki Bolesnej ku zachodniemu wejściu do świątyni. Wtedy wierni mogą zobaczyć drogocenną monstrancję - dar króla Zygmunta III Wazy, niesioną pod zabytkowym baldachimem. Na zakończenie procesji celebrans udziela zebranym w kościele błogosławieństwa Najświętszym Sakramentem. Następnie wierni mają możliwość osobistej modlitwy przed cudownym wizerunkiem. Od 2006 r. wierni gromadzą się także wieczorem w kościele na modlitwie różańcowej, po której następuje Apel Maryjny i zasłonięcie cudownego obrazu ${ }^{216}$. Przez cały dzień pielgrzymi nawiedzają kościół, a potem w swoich intencjach obchodzą na kolanach ołtarz z wizerunkiem Matki Bożej. Według relacji księży kustoszy 15 sierpnia przybywa do sanktuarium w zorganizowanych grupach i indywidualnie od 5.000 do 9.000 pątników ${ }^{217}$. Pozostałe uroczystości nie gromadzą już tak dużej liczby wiernych, co pozwala na celebracje w kościele, który wówczas jest szczelnie wypełniony pielgrzymami.

Od wielu lat do celebrowania sumy odpustowej są zapraszani biskupi i kapłani z dekanatu grójeckiego i archidiecezji warszawskiej, a także spoza jej granic. Pierwszą rocznicę koronacji cudownego obrazu sumę odpustową odprawił bp Jerzy Modzelewski ${ }^{218}$. W latach 80. i 90. na uroczystość Wniebowzięcia NMP do sanktuarium przybywał często bp Władysław Miziołek. Tak było w roku 1984, kiedy w Lewiczynie obchodzono jubileusz 300 lat od ogłoszenia dekretem kościelnym obrazu, jako cudownego. Wspomniany biskup w asyście duchowieństwa dekanatu grójeckiego odprawił wówczas mszę świętą oraz wygłosił homilię ${ }^{219}$.

\footnotetext{
${ }^{213}$ APL 55/2, Księga wizytacji parafii Lewiczyn, s. 2.

${ }^{214}$ APL 41/1, Kronika parafialna 1945-1980, s. 47-48.

${ }^{215}$ APL 55/2, Księga wizytacji parafii Lewiczyn, s. 75-76.

${ }^{216}$ APL 42/2 Kronika parafialna 1980-2012, s. 147-148.

${ }^{217}$ APL 42/2 Kronika parafialna 1980-2012, s. 121.

${ }^{218}$ Tamże, s. 68.

${ }^{219}$ APL 49, Księga pamiątkowa 1966, s. 65-66.
} 
W święto Matki Kościoła 31 maja 1982 r. mszy św. przewodniczył dziekan grójecki ks. Ryszard Okiński, a koncelebrowali ją księża: Czesław Sadłowski ze Zbroszy Dużej oraz Henryk Michalak z Leśnej Polany. Spowiadali księża: Stanisław Sobótka z Tarczyna, Stanisław Kuć z Mrokowa, Stanisław Urbanek z Belska Dużego, Paweł Heintsch z Jeziórki oraz Ireneusz Wojciechowski z Prażmowa ${ }^{220}$.

Na uroczystość Matki Kościoła w 1994 r. przybył do Lewiczyna bp Marian Duś, a uroczystość Zwiastowania Pańskiego 25 marca 1995 r, i odpust tego dnia rozpoczął obchody dwudziestopięciolecia koronacji cudownego obrazu. Sumie odpustowej przewodniczył ks. Grzegorz Kalwarczyk, kanclerz Kurii Metropolitalnej w Warszawie ${ }^{221}$.

W 1997 r. w uroczystość Matki Kościoła msze św. odpustową odprawił ks. infułat Zdzisław Król, a uczestniczyli w niej także liczni duchowni z parafii dekanatu oraz zorganizowane grupy pątników. Kolejny raz ksiądz infułat przybył na odpust 15 sierpnia 2000 r., w dniu kończącym uroczyste obchody dwudziestopięciolecia koronacji obrazu Matki Bożej222. W odpuście, według relacji ks. Piotrowskiego, brało udział ponad 5.000 ludzi.

W roku 1998 na zaproszenie opiekuna sanktuarium odwiedził je bp Józef Zawitkowski, sufragan łowicki, uczestnik koronacji w 1975 roku. Ponownie gościł on w Lewiczynie w dniu głównego odpustu w 2001 r., celebrował mszę św. oraz wygłosił kazanie o znaczeniu kultu Matki Bożej Lewiczyńskiej dla ziemi grójeckiej.

W 2004 roku sumę odpustową na zaproszenie proboszcza, ks. Z. Karasia, odprawił ks. Stanisław Laskowski, dziekan dekanatu grójeckiego ${ }^{223}$. Na odpusty przybywają wierni wraz ze swymi duszpasterzami z parafii dekanatu grójeckiego oraz dekanatów sąsiednich ${ }^{224}$. Duchowni służą pomocą przy spowiadaniu pątników oraz rozdawaniu komunii.

Oprócz świąt maryjnych w Lewiczynie, uroczystości odpustowe przypadają w święta patronów parafii świętych Wojciecha oraz Marcina. Zgodnie z przyjętą od wielu lat tradycją w dniu wspomnienia patrona Polski przybywają do Lewiczyna poprzedni proboszczowie.

\section{b) Ruch pielgrzymkowy i jego zasięg}

Ruch pielgrzymkowy związany z funkcjonowaniem sanktuarium maryjnego w Lewiczynie można podzielić na związany z odpustami odbywającymi się $\mathrm{w}$ sanktuarium oraz z pielgrzymkami przybywającymi do Lewiczyna $\mathrm{w}$ innych okolicznościach. Bardzo wielu pielgrzymów przybywało do sanktuarium indywidualnie. Na duże uroczystości odpustowe organizowane były jednak pielgrzymki mniejszych bądź większych grup pątniczych, w zależności od terminu odpustu. Były to przeważnie grupy, pokonujące pieszo drogę do sanktuarium lewiczyńskiego ze swojej rodzimej parafii bądź miejscowości.

\footnotetext{
${ }^{220}$ Tamże, s. 44-45.

${ }^{221}$ APL 42/2 Kronika parafialna 1980-2012, s. 93-97.

${ }^{222}$ Tamże, s. 108-123.

${ }^{223}$ Tamże, s. 124-141.

${ }^{224}$ Zob. Ruch pielgrzymkowy i jego zasięg.
} 
Znajdujące się w archiwum parafialnym księgi pozwalają prześledzić w pewnym stopniu ruch pielgrzymkowy związany $\mathrm{z}$ odpustami obchodzonymi w sanktuarium lewiczyńskim.

Na główny odpust 15 sierpnia, przybywali głównie wierni wraz ze swymi duszpasterzami w zorganizowanych grupach z Grójca, Jasieńca, Goszczyna oraz Zbroszy Dużej225. Tych ostatnich prowadził do Lewiczyna ks. Czesław Sadłowski, organizator i pierwszy proboszcz parafii pw. św. Jana Chrzciciela.

$\mathrm{Na}$ święto Matki Kościoła przybywają co roku do sanktuarium piesze pielgrzymki z parafii Goszczyn, a w ostatnią niedzielę lipca - z Błędowa i Mogielnicy. W święto Narodzenia NMP tradycyjnie przychodzi pielgrzymka z Łęczeszyc. Po utworzeniu w Grójcu drugiej parafii pw. Miłosierdzia Bożego, grupy pielgrzymkowe zaczęły przybywać do sanktuarium na uroczystość odpustową w dniu 8 września 226 .

W latach 80 . XX wieku, kiedy w Lewiczynie obchodzono historyczne rocznice - 300 lat od chwili ogłoszenia obrazu cudownym (1984) oraz dziesiątą rocznicę koronacji wizerunku Matki Bożej (1985), liczba pielgrzymów nawiedzających sanktuarium rosła, co z zadowoleniem odnotowywali wizytatorzy, zachęcając księży kustoszy do jeszcze wytrwalszej pracy na rzecz szerzenia kultu. Ożywienie ruchu pielgrzymkowego miało związek z nawiedzeniami obrazu Matki Bożej Lewiczyńskiej w wielu parafiach dekanatu grójeckiego, oraz sąsiednich dekanatów w latach 1975-1984227.

Do Lewiczyna zmierzają pielgrzymi przez cały rok. Możliwość ogólnego prześledzenia tego ruchu dają księgi znajdujące się w archiwum parafialnym. Założona przez ks. J. Makowskiego Księga pamiątkowa Sanktuarium Lewiczyńskiego zawiera wpisy pątnicze z lat 1966-2009, wyłączając część wpisów znajdujących się w innej księdze, założonej przez ks. Dusiło, a obejmującej wpisy z lat 1983-1993228. Z zamieszczonych adnotacji można się dowiedzieć, skąd przybyła dana grupa. Czasem znajdują się informacje o ilości pątników, bądź podpisy wszystkich uczestników pielgrzymki. Przeważnie widnieje także w księdze data wpisu oraz numer porządkowy w obrębie danego roku. Ozdobą wspomnianej księgi są wpisy biskupów uczestniczących w 1975 r. w koronacji, słowa podziękowania za zaproszenie na uroczystości do Lewiczyna oraz podpisy dostojnych gości i celebransów ${ }^{22}$. W księdze tej znajdują się również wpisy biskupów wizytujących parafię lub przybywających, by uczestniczyć w uroczystościach odpustowych, wpisy księży przybywających do sanktuarium, by przeżywać w nim dzień wspólnoty, wpisy grup oazowych, odbywających tu rekolekcje w sierpniu 1982 r. i lutym 1984 r., a także pielgrzymujących alumnów oraz wykładowców Wyższego Metropolitalnego Seminarium Duchownego w Warszawie ${ }^{230}$.

${ }^{225}$ APL 49, Księga pamiątkowa 1966, s. 123-125.

${ }^{226}$ APL 49, Księga pamiątkowa 1966, s. 117-125.

${ }^{227}$ APL 54/1 Księga wizytacji, s. 160; APL 49, Księga pamiątkowa 1966, s. 68.

${ }^{228}$ APL 50/1 Księga podziękowań i próśb do Matki Bożej Pocieszycielki Strapionych w Lewiczynie 15.08.1983-18.09.1993, s. 12-56; APL 51/2 Księga podziękowań i próśb do Matki Bożej Pocieszycielki Strapionych w Lewiczynie 19.09.1993, s. 1-22.

${ }^{229}$ APL 49, Księga pamiątkowa 1966, s. 25-26.

${ }^{230}$ Tamże, s. 29-74. 
W 2001 r. sanktuarium odwiedzili pielgrzymi z Krakowa, była tu także pielgrzymka osób życia konsekrowanego z diecezji radomskiej oraz pielgrzymki autokarowe z Cieszyna, Siedlec, Lublina, Świdnika, Puław, Podkowy Leśnej i Radomia. Swoje wpisy pozostawili też pątnicy zmierzający na Jasną Górę. Można napotkać wpisy w języku niemieckim oraz informacje o grupie pielgrzymów z Hiszpanii. W sanktuarium modlili się także przedstawiciele różnych grup zawodowych: pielęgniarek, bankowców, przewodników turystycznych i lekarzy ${ }^{231}$.

W roku 2004 - czyli roku wielkiego jubileuszu obecności cudownego obrazu w lewiczyńskiej świątyni, odnotowano w Księdze Pamiątkowej 48 wpisów pątniczych. O wstawiennictwo Matki Bożej prosili maturzyści, dzieci pierwszokomunijne, pielgrzymka osób niepełnosprawnych wraz z opiekunami z diecezji gdańskiej, słuchacze diecezjalnego Radia Józef, grupy ministrantów i bielanek ${ }^{232}$. Również w kolejnych latach księga zapełniała się wpisami pątników, proszących o opiekę, dziękujących za łaskę nawiedzenia Jej cudownego obrazu, proszących o pomyślność dla siebie, swych rodzin, parafii i Ojczyzny ${ }^{233}$.

\section{Inne przykłady kultu maryjnego w Lewiczynie}

\section{a) Nabożeństwa i modlitwy}

Ks. J. Makowski, starając się po swoim przybyciu do Lewiczyna na nowo odrodzić kult cudownego obrazu Matki Bożej, rozpropagował zapomniany tekst starej modlitwy i pieśni śpiewanej przez stulecia w lewiczyńskim kościele podczas obchodów świąt maryjnych. Dzięki temu weszły one na stałe do modlitw zanoszonych w sanktuarium ${ }^{234}$. Dodatkowo ks. J. Makowski wprowadził specjalne nabożeństwo odprawiane w każdą sobotę o godzinie 18:00, podczas którego wierni mogli przed cudownym obrazem zanosić swoje modlitwy i prośby. Od maja 1965 r., z inspiracji proboszcza wierni przed niedzielną, poranną mszą św. zaczęli śpiewać Godzinki o Niepokalanym Poczęciu NMP, po sumie natomiast śpiewano Anioł Pański ${ }^{235}$.

W okresie pełnienia funkcji kustosza przez ks. Aulicha, nabożeństwo do Matki Bożej zaczęto odprawiać tylko w pierwszą sobotę każdego miesiąca. Proboszcz dbał o to, by pozostałe formy pobożności maryjnej były ze względu na sanktuarium stale kultywowane ${ }^{236}$.

Dużych zmian programu nabożeństw związanych z kultem maryjnym w sanktuarium dokonał ks. Z. Karaś. Wprowadził on nowe, niepraktykowane wcześniej w lewiczyńskim sanktuarium formy pobożności. Nabożeństwo do Matki Bożej Lewiczyńskiej miało się od tej chwili odbywać w każdą sobotę. Inicjatywą ks. Karasia było wprowadzenie w sanktuarium różańca fatimskiego, w 13. dniu każdego miesiąca, od maja do października. Nabożeństwo to zaczęło się rozwijać

\footnotetext{
${ }^{231}$ Tamże, s. 77-103.

${ }^{232}$ Tamże, s. 105-117.

${ }^{233}$ Tamże, s. 117-160.

${ }^{234}$ Kiełbowska, Parafia Lewiczyn, s. 123.

${ }^{235}$ Tamże, s. 94.

${ }^{236}$ APL 54/1 Księga wizytacji, s. 39.
} 
w związku z podjętą w 2009 r. budową kapliczek różańcowych oraz pielgrzymką do Fatimy w 2010 r. Parafianie-uczestnicy tej pielgrzymki zakupili do sanktuarium figurę Matki Bożej Fatimskiej, którą zaczęto nosić w procesjach w trakcie nabożeństw fatimskich. Ks. Karaś, dbając o formację członków kół różańcowych, raz w miesiącu organizował dla nich specjalną konferencję połączoną z mszą św. ${ }^{237}$

\section{b) Pieśni}

Pielgrzymi przybywający do Lewiczyna mogą zanosić swoje modlitwy do Matki Bożej także w formie pieśni, a lewiczyńskie sanktuarium może się pochwalić pieśniami skomponowanymi specjalnie dla niego.

Najstarszą znaną pieśnią, opowiadającą o dziejach, kulcie i cudach doświadczanych za przyczyną Matki Bożej Lewiczyńskiej jest pieśń zaczynająca się od słów: Ty, której obraz w tej świątyni stynie ${ }^{238}$, której tekst odnalazł ks. J. Makowski i rozpropagował w sanktuarium. Język pieśni wskazuje na jej pochodzenie z XVIII-XIX wieku. Autorem słów mógł być Antoni Crutta, dyplomata związany z dworem króla Stanisława Augusta Poniatowskiego, żyjący w latach 1727-1814, który na starość osiadł w Lewiczynie. Codziennie modlił się w kościele przed cudownym obrazem i być może również ułożył tę pieśń na cześć Matki Bożej Lewiczyńskiej ${ }^{239}$.

Kolejna pieśń powstała z okazji koronacji cudownego obrazu. Pani Ziemi Grójeckiej, nawiązuje do tytułu nadanego Matce Bożej Lewiczyńskiej przez kard. S. Wyszyńskiego, w dniu koronacji cudownego obrazu. Pieśń ta jest śpiewana często na rozpoczęcie nabożeństwa przed cudownym obrazem ${ }^{240}$.

Najnowsza Pieśń do Matki Bożej Lewiczyńskiej została skomponowana w 2004 r. na prośbę ks. P. Piotrowskiego, z okazji jubileuszu 400-lecia obecności cudownego obrazu w Lewiczynie ${ }^{241}$. Jej słowa ułożył bp Józef Zawitkowski, który jako kapłan uczestniczył w uroczystościach koronacyjnych oraz często przybywał na odpust do sanktuarium. Melodia jest dziełem ks. Wiesława Kądzieli, wykładowcy muzyki kościelnej w Wyższym Metropolitalnym Seminarium Duchownym w Warszawie ${ }^{242}$.

\section{c) Dewocjonalia i wydawnictwa}

Mówiąc o dewocjonaliach związanych z sanktuarium w Lewiczynie, mamy przede wszystkim na myśli reprodukcje cudownego obrazu Matki Bożej. Obrazki $\mathrm{z}$ wizerunkiem czczonym w lewiczyńskim sanktuarium powstawały w miarę potrzeb ośrodka kultowego i były formą szerzenia czci Matki Bożej wśród parafian. Nabywali je także pątnicy, przybywający na odpusty oraz otrzymywały dzieci, jako pamiątkę Pierwszej Komunii Świętej.

\footnotetext{
${ }^{237}$ APL 42/2 Kronika parafialna 1980-2012, s. 150-165.

${ }^{238}$ Słowa pieśni „Ty, której obraz w tej świątyni słynie”, patrz Aneks.

${ }^{239}$ B.J., Gawecki, Antoni Łukasz Crutta 1727-1814, Warszawa 1978, s. 29-36.

${ }^{240}$ Słowa pieśni Pani Ziemi Grójeckiej, patrz Aneks 2.

${ }^{241}$ Słowa pieśni Pieśń do Matki Bożej Lewiczyńskiej, patrz Aneks 3.

${ }^{242}$ G. Kalwarczyk, Jubileuszowy rocznik, w: Jubileuszowy rocznik Archidiecezji Warszawskiej, t. 1 Osoby i Instytucje, Warszawa 1998, s. 253.
} 
Po koronacji cudownego obrazu ks. Makowski zamówił w 1976 r. kopie ob$\mathrm{razu}^{243}$. Kolejni proboszczowie dbali, by obrazki z wizerunkiem Matki Bożej były zawsze dostępne dla wiernych. Niestety, nie udało się ustalić, gdzie powstały poszczególne reprodukcje. Obrazki z wizerunkiem Matki Bożej zostały wydane po obu renowacjach cudownego obrazu w 1967 i 2004 r., czyli w czasie, kiedy kustoszami lewiczyńskiego sanktuarium byli odpowiednio księża: J. Makowski i P. Piotrowski. Ks. Piotrowski zlecił też druk w wielkim formacie reprodukcji cudownego obrazu, które miały trafić do wszystkich rodzin w parafii. Nowe obrazki zamówił także ks. Zdzisław Karaś. Przedstawiały one obraz Matki Bożej przybrany w sukienki i korony lub bez nich ${ }^{244}$.

Pielgrzymi mogli też nabywać medaliki z wyobrażeniem cudownego obrazu. Tego typu dewocjonalia rozpropagował wśród wiernych ks. S. Dusiło 245 . Wybicie złotych i srebrnych medalików zlecił w 2002 r. także ks. P. Piotrowskii ${ }^{246}$.

Przybliżeniu dziejów miejsca świętego i jego zabytków służą kolorowe broszury oraz pocztówki ze zdjęciami sanktuarium.

\section{Zakończenie}

Przedstawiony zarys dziejów sanktuarium pozwala lepiej zrozumieć, z jakimi trudnościami i uwarunkowaniami stykali się kolejni opiekunowie cudownego obrazu. Jego koronacja, dokonana w dniu 10 sierpnia 1975 r., stanowiła nowy impuls do rozszerzania kultu wizerunku. Nowe formy pobożności, wcześniej niepraktykowane, takie jak peregrynacje obrazu w parafiach ziemi grójeckiej i poza jej granicami, stały się podstawą kultu promieniującego na cały obszar południowego Mazowsza. Spowodowały one napływ pielgrzymów i rozkwit lewiczyńskiego sanktuarium w ciągu ostatnich lat. Coraz większe rzesze wiernych gromadziły uroczystości odpustowe, uświetniane obecnością hierarchów oraz duchowieństwa $\mathrm{z}$ wielu dekanatów diecezji. O bogactwie życia duchowego oraz zaangażowaniu kustoszy w ciągłe pogłębianie czci do Matki Bożej Lewiczyńskiej świadczą przyciągające pielgrzymów liczne nabożeństwa, pieśni i modlitwy, jak również poświęcone sanktuarium wydawnictwa oraz dewocjonalia, będące dowodem żywotności zapoczątkowanego przed dziesięcioleciami dzieła.

słowa kluczowe: słowa kluczowe: Sanktuarium, Lewiczyn, Matka Boża, Stefan Wyszyński, XX wiek, Pielgrzymki, Archidiecezja Warszawska

\footnotetext{
${ }^{243}$ APL 41/1, Kronika parafialna 1945-1980, s. 67.

${ }^{244}$ Niektóre reprodukcje obrazu Matki Bożej można zobaczyć w aneksie.

${ }^{245}$ APL 42/2 Kronika parafialna 1980-2012, s. 37.

${ }^{246}$ APL 42/2 Kronika parafialna 1980-2012, s. 135.
} 


\section{Źródła}

\section{BIBLIOGRAFIA}

Archiwum Parafii Lewiczyn (APL)

$\mathrm{Nr}$ 18. Dokumenty dotyczące remontu kościoła parafialnego w Lewiczynie.

Nr 26. Księga Fundi inscripti Parafii Lewiczyn od 1945 roku.

$\mathrm{Nr}$ 41/1. Kronika parafialna 1945-1980.

$\mathrm{Nr}$ 42/2. Kronika parafialna 1980-2012.

$\mathrm{Nr}$ 49. Księga pamiątkowa 1966.

Nr 50/1. Księga podziękowań i próśb do Matki Bożej Pocieszycielki Strapionych w Lewiczynie 15.08.1983-18.09.1993.

Nr 51/2. Księga podziękowań i próśb do Matki Bożej Pocieszycielki Strapionych w Lewiczynie 19.09.1993.

Nr 54/1. Księga wizytacji - Liber visitationum episcopalium et decanalium ecclesiae Levicinensis ab anno 1891-1982.

$\mathrm{Nr} 55 / 2$. Księga wizytacji parafii Lewiczyn.

$\mathrm{Nr}$ 60. Decyzje i nakazy wojewódzkiego konserwatora zabytków.

- Decyzja nr. 609/2003. Zgoda na przeprowadzenie prac konserwatorskich przy obrazie Matki Boskiej Lewiczyńskiej z ołtarza głównego kościoła parafialnego w Lewiczynie.

- Opis historyczny o kulcie, starożytności i wartości historycznej cudownego obrazu.

- Opis prac konserwatorskich przy sukience Matki Bożej Lewiczyńskiej.

- Prośba o zgodę na wykonanie prac konserwatorskich przy obrazie Matki Bożej Lewiczyńskiej.

- Rok maryjny w Sanktuarium Matki Bożej w Lewiczynie Pani Ziemi Grójeckiej.

\section{Opracowania}

Bryndza Wojciech, Krótka wiadomość o cudownym obrazie N.M.P. w Lewiczynie, Warszawa 1906.

Bryndza Wojciech, Księga cudów i łask Najświętszej Bogarodzicy Maryi w kościele lewiczyńskim zostającej, Warszawa 1911.

Derewenda Robert., Dzieło Wiary. Historia Ruchu Światło-Życie 1950-1985, Kraków 2010 .

Dudziak Jan, Prawno-kanoniczne koncepcje sanktuarium, „Tarnowskie Studia Teologiczne", t. 9, Tarnów 1983, s. 60-73.

Fridrich Alojzy, Historie cudownych obrazów NMP w Polsce, t. 3, Kraków 1908.

Galicka Izabella, Sygietyńska Hanna, Erazm Wąsowski - nieznany malarz XVII w. i jego dzieło w Lewiczynie, w: „Biuletyn Historii Sztuki” 1(1970), s. 69-81.

Gawecki Bolesław Józef, Antoni Łukasz Crutta 1727-1814, Warszawa 1978.

Gołąb Tomasz, Madonna, co z cedrowej deski pociesza, w: „Gość Niedzielny”, 29(2001), s. 14.

Kalwarczyk Grzegorz, Dekanat grójecki w archidiecezji warszawskiej, Warszawa 2001.

Kalwarczyk Grzegorz, Jubileuszowy rocznik, w: Jubileuszowy rocznik Archidiecezji Warszawskiej, t. 1 Osoby i Instytucje, Warszawa 1998, s. 253.

Kiełbowska Zofia, Parafia Lewiczyn w latach 1945-1995, Warszawa 2001.

Kolberg Oskar, Dzieła zebrane, t. 24, Wrocław-Poznań 1963.

Krukowski Józef, Odpust, w: Encyklopedia katolicka, t. 14, Lublin 2010, kol. 342-344.

Lubomirski Tadeusz, Księgi Ziemi Czerskiej, Warszawa 1879.

Łeszczyński Grzegorz, Kapłan niezłomny. Ksiądz Czesław Sadłowski, „Biuletyn Instytutu Pamięci Narodowej”, 10(2008), s. 67-68. 
Łeszczyński Grzegorz, Początki parafii w Zbroszy Dużej, Warszawa 2007.

[Makowski Jan.], Opis historyczny o kulcie, starożytności i wartości artystycznej cudownego obrazu Matki Bożej Lewiczyńskiej, [Lewiczyn 1973].

Malej Witold, Sanktuaria maryjne Archidiecezji Warszawskiej, Rzym 1966.

Małecki Henryk, Dziurok Adam, Sanktuaria odpustu jubileuszowego w Archidiecezji Warszawskiej, Warszawa 2000.

Marianie, red. J. Bukowicz, Stockbridge 1968.

Matyjas Remigiusz, Kult Matki Bożej Lewiczyńskiej. Cuda i wyznawcy XVII-XVIII wiek, Warszawa 1992.

Matyjas Remigiusz, Lewiczyn. Z dziejów kultu maryjnego, „Mówią Wieki”, 7 (1991) s. 24-28.

Matyjas Remigiusz, Smak XX w., Grójec 1998.

Matyjas Remigiusz, Z dziejów Grójecczyzny, Grójec 1999.

Matyjas Remigiusz, Powiat grójecki na scenie wieków, Grójec 2010.

Matyjas Remigiusz, Powiat grójecki w latach 1945-1975, Grójec 2006.

Nowacki Józef, Archidiecezja poznańska w granicach historycznych i jej ustrój, Poznań 1964.

Odezwa do wiernych archidiecezji warszawskiej przed uroczystościami koronacyjnymi w Lewiczynie i Głogowie, „Wiadomości Archidiecezjalne Warszawskie”, 7 (1975) s. $340-342$.

Pałęcki Waldemar, Sanktuarium, w: Encyklopedia katolicka, t. 17, red. S. Wilk, L. Adamowicz, J. Fert, Lublin 2012, s. 1058-1059.

P.B., Dwudziesta rocznica koronacji Matki Bozej w Lewiczynie, „Wiadomości Archidiecezjalne Warszawskie", 6 (1995) s. 752.

Perzyna Krzysztof, Sanktuarium maryjne w Lewiczynie 1962-2012, Lublin 2013, mps praca magisterska, Archiwum KUL.

Roszkowski Wojciech, Historia Polski 1914-2005, wyd. 11, Warszawa 2009.

Rytel-Andrianiuk Pawel, Sanktuarium i parafia Trójcy Przenajświętszej i Świętej Anny w Prostyni, wyd. 2, Drohiczyn-Rzym-Oksford 2011.

Sowa Andrzej Leon, Historia polityczna Polski 1944-1991, Kraków 2011.

Spyk Agnieszka, Spyk Robert, Zamki i warownie ziemi mazowieckiej, Warszawa 2002.

Szeląg Zdzisław, Grójecczanie sami o sobie. Antologia korespondencji prasowej lat 18891959. Cz.2 1906-1946, Grójec 2008.

Wiśniowski Jacek A., Kościoły drewniane Mazowsza, Pruszków 1998.

Wysocki Jan, Powstanie diecezji warszawskiej, Leszno k. Błonia 1998.

Z dawna Polski Tyś Królową. Przewodnik po sanktuariach maryjnych, wyd. 5, popr. i uzup., Szymanów 1999.

Zaleski Wincenty, Sanktuaria polskie, Warszawa 1988. 


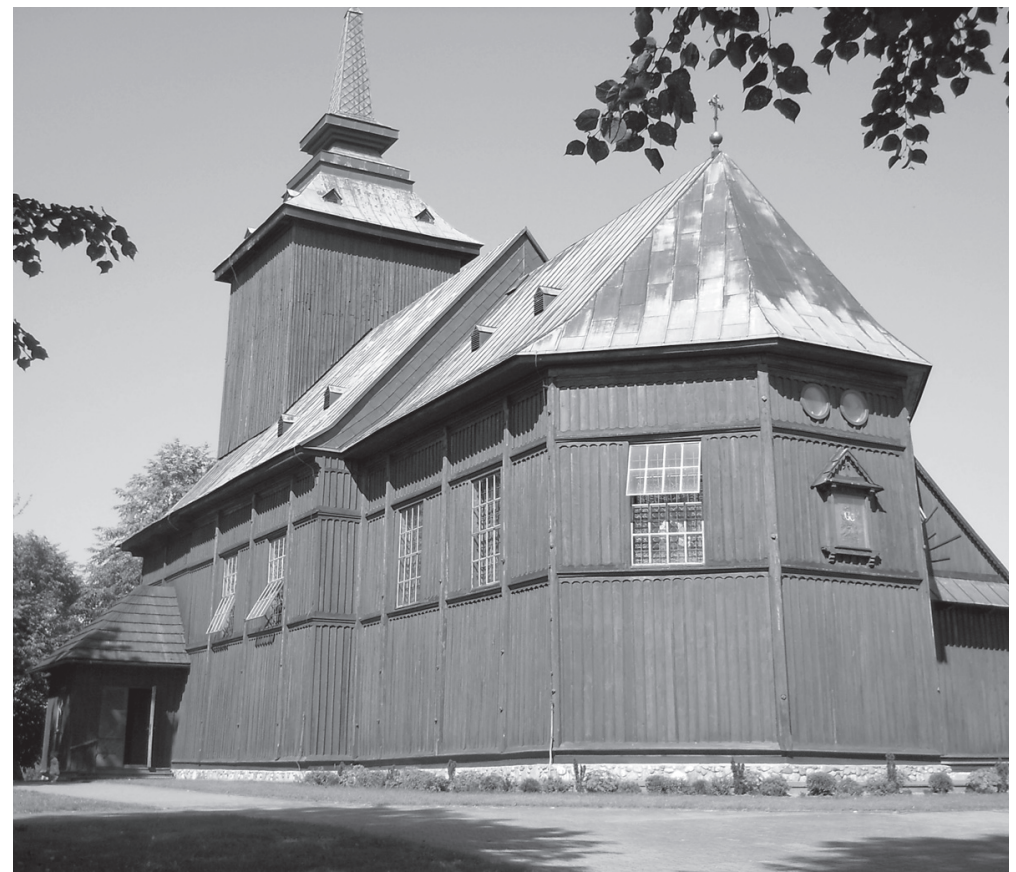

Fot. 1. Widok kościoła w Lewiczynie. Fot. Krzysztof Perzyna.

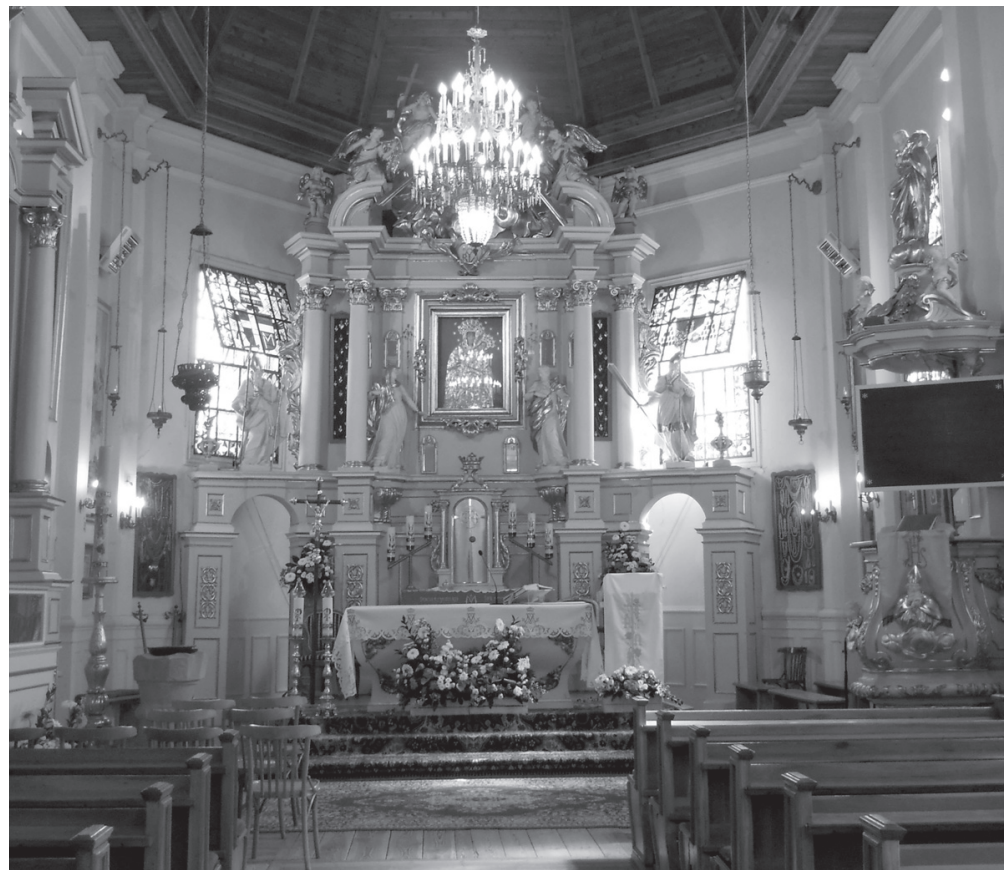

Fot. 2. Ołtarz główny z cudownym wizerunkiem Matki Bożej Lewiczyńskiej. Fot. Krzysztof Perzyna 


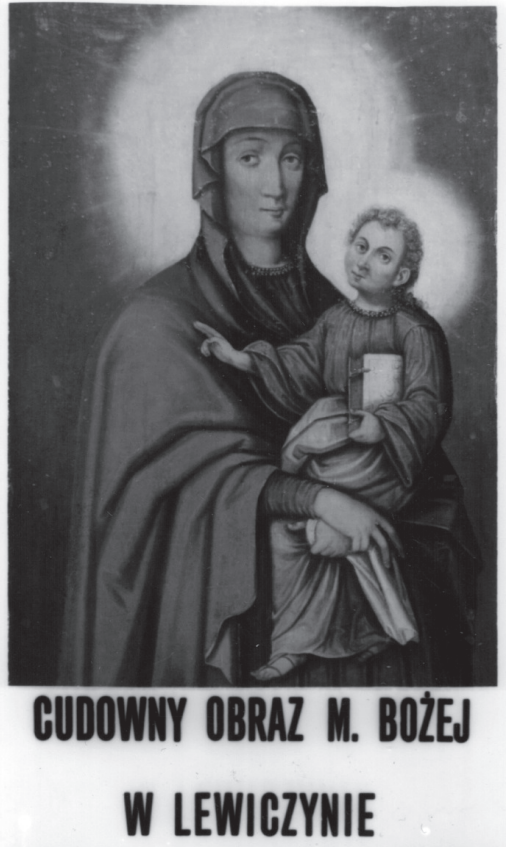

Fot. 3. Obrazek z lat 70. XX wieku z wizerunkiem cudownego obrazu. Ze zbiorów autora.

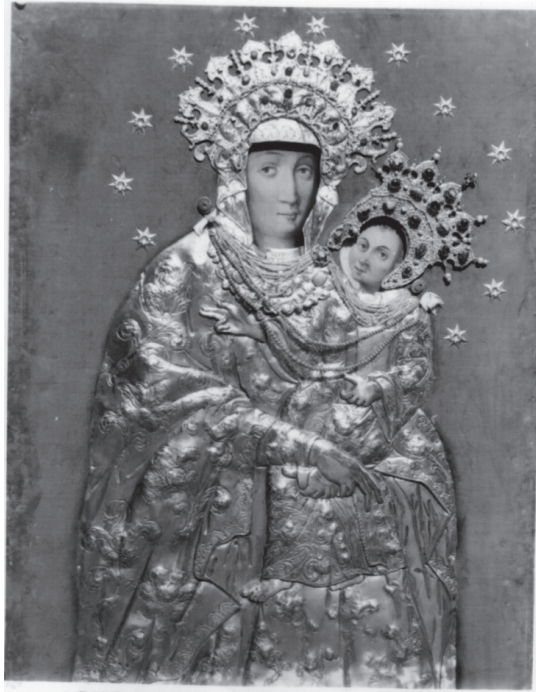

CUDOWNY OBRAZ M. BOZEJ

W LEWICZYNIE

Fot. 4. Obrazek z lat 70. XX wieku z wizerunkiem cudownego obrazu. Ze zbiorów autora. 


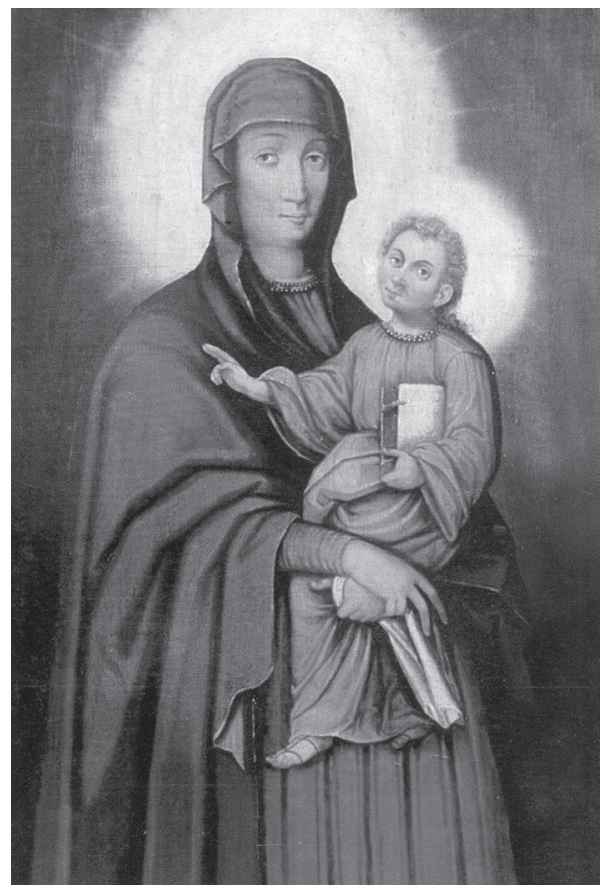

Fot. 5. Obraz po renowacji, 2004 r. Ze zbiorów autora.

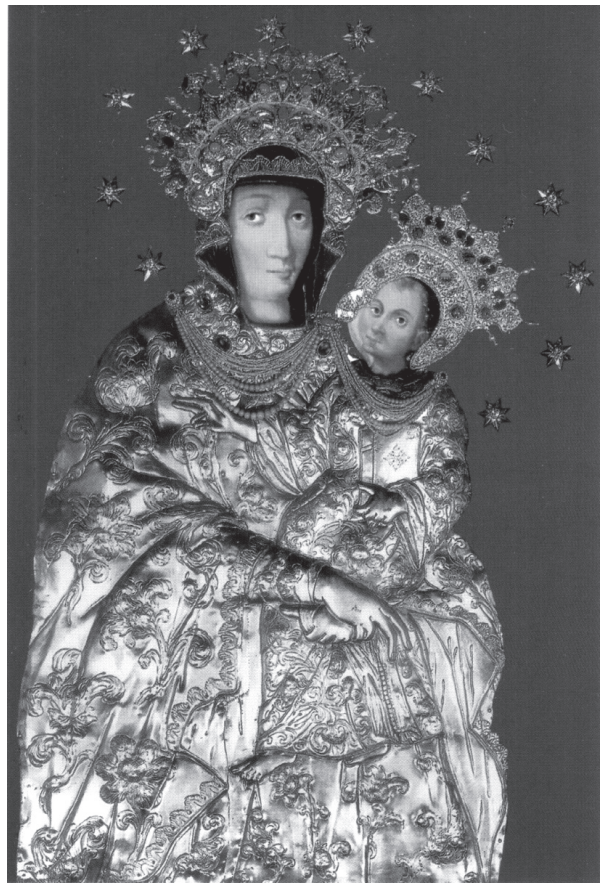

Fot. 6. Obraz w sukience, 2006 r. Ze zbiorów autora. 


\section{ANEKS}

Pieśń do Matki Bożej Lewiczyńskiej, słowa: bp Józef Zawitkowski melodia: ks. Wiesław Kądziela

Ref. Lewiczyńska Dobra Matko, śliczna Pani naszej ziemi; pociesz chorych i strapionych i nas pociesz, gdy płaczemy, i nas pociesz, gdy płaczemy.

1. Miej w opiece nasze domy i rodzimy, i sąsiadów, Matko kwiatów i owoców, pobłogosław naszym sadom

2. Najpiękniejszy kwiecie ziemi, Matko Zielna i kwiatowa; sady nasze i ogrody, i od złego nas zachowa

3. Uproś, Matko, urodzaje i daj czas szczęśliwych zbiorów; byśmy się dzielili z braćmi, żyli w zgodzie i pokoju.

$* * *$

Stara pieśń, śpiewana przed obrazem Matki Bożej Lewiczyńskiej

1. Ty, której obraz w tej świątyni słynie, Jedyna nasza po Bogu otucha!

Biegniemy Matko, po tej łez dolinie, Uzdrów nas wszystkich i dodawaj ducha.

2. Tu wszyscy społem, cześć Ci oddajemy.

Tu w Lewiczynie, miejsceś swe obrała.

Nie gardzisz wioską, pagórkiem i nami!

Gdzie w środku Polski łaską zajaśniała.

3. W obrazie sławnym o Matko Jedyna, Obcujesz z dawna ze swymi dziatkami. Sił nam dodawaj byśmy Twego Syna, Z którym przebywasz chwalili cnotami. 
4. Twa wola była by ten obraz sławny,

Przebywał w miejscu, gdzie był kościół dawny.

By od Twych dzieci był tu nawiedzany,

Jako cudowny wszystkim ogłaszany.

5. Gdy nieprzyjaciel tu swą moc wywierał,

I wszystkie siły na Twój lud poruszył,

Mieczem, szturmami na wiernych nacierat,

Ty wiarę wspierasz, moc Twa pogan kruszy!

\section{THE MARIAN SANCTUARY IN LEWICZYN IN THE 20TH \\ AND 21ST CENTURIES AGAINST A BACKGROUND OF THE HISTORY OF THE VILLAGE AND PARISH}

\section{Summary}

The article presents the history of the cult centre, its revival and development in the 20th and 21st centuries. Lewiczyn is sometimes referred to as „small Częstochowa” of the Grójec land. The coronation of the image of Our Lady of Lewiczyn on 10 August 1975 gave new impetus to the expansion of the cult of the image. New forms of piety, (not practiced before) such as peregrinations of the image throughout the parishes of the Grójec land and beyond its borders, expanded the cult into the lands of southern Mazovia. Parish fairs, which were honoured by the presence of the hierarchs and clergy of the diocese, attracted more and more people.

The richness of the spiritual life and the involvement of priests in the continuous deepening reverence for Our Lady of Lewiczyn is evidenced by numerous devotions, songs and prayers as well as publications concerning the sanctuary and devotional items, which are proof of the vitality of the work initiated decades before.

Keywords: sanctuary, Lewiczyn, Mother of God, Stefan Wyszyński, 20th century, pilgrimages, the Archdiocese of Warsaw 